\title{
Large Animal Models of Inherited Retinal Degenerations: A Review
}

\author{
Paige A. Winkler, Laurence M. Occelli and Simon M. Petersen-Jones * \\ Department of Small Animal Clinical Sciences, Veterinary Medical Center, Michigan State University, East \\ Lansing, MI 48824, USA; winkle38@msu.edu (P.A.W.); occelli@msu.edu (L.M.O.) \\ * Correspondence: peter315@msu.edu; Tel.: +1-517-353-3278
}

Received: 1 March 2020; Accepted: 31 March 2020; Published: 3 April 2020

\begin{abstract}
Studies utilizing large animal models of inherited retinal degeneration (IRD) have proven important in not only the development of translational therapeutic approaches, but also in improving our understanding of disease mechanisms. The dog is the predominant species utilized because spontaneous IRD is common in the canine pet population. Cats are also a source of spontaneous IRDs. Other large animal models with spontaneous IRDs include sheep, horses and non-human primates (NHP). The pig has also proven valuable due to the ease in which transgenic animals can be generated and work is ongoing to produce engineered models of other large animal species including NHP. These large animal models offer important advantages over the widely used laboratory rodent models. The globe size and dimensions more closely parallel those of humans and, most importantly, they have a retinal region of high cone density and denser photoreceptor packing for high acuity vision. Laboratory rodents lack such a retinal region and, as macular disease is a critical cause for vision loss in humans, having a comparable retinal region in model species is particularly important. This review will discuss several large animal models which have been used to study disease mechanisms relevant for the equivalent human IRD.
\end{abstract}

Keywords: large animal model; inherited retinal disease; progressive retinal atrophy; retinitis pigmentosa; Leber congenital amaurosis; achromatopsia; congenital stationary night blindness

\section{Introduction}

Large animal models for inherited retinal degenerations (IRDs) have been identified within populations of dogs, cats, sheep, horses and, more recently, non-human primates (NHP). Many different IRDs have been identified in pedigree dogs, most of which mimic retinitis pigmentosa (RP) or Leber congenital amaurosis (LCA). The term "progressive retinal atrophy" (PRA) is used to describe this group of photoreceptor degenerations. In some instances, more detailed descriptive terms such as rod-cone dysplasia or progressive rod cone degeneration have been used. Common dog breeding practices have tended to bring out recessive conditions and have made the pedigree dog a rich source of models for inherited disease, including IRDs. Engineered large animal IRD models such as transgenic pigs have also been produced [1]. With advances in gene editing technologies, further models are likely to be produced in species such as pigs and NHPs and possibly even cats and dogs. The advantages of large animal models over laboratory rodent models of IRDs include the similarity in the size of the eye to that of man [2]. This is of particular importance for the development of translational therapies because it allows identical surgical delivery approaches to be used in the animal model to those that will be eventually used in human patients. NHPs are obviously close relatives to humans, making them attractive models. However, only a few spontaneous IRDs in primates have been identified $[3,4]$, although steps are being taken to identify more animals with disease-causing mutations and to use genome editing to generate additional models with mutations in genes of importance, either for 
germline transmission (see [5] for a review) or somatic gene knockout [6]. Another major advantage of large animal models is the presence of a retinal region equivalent to the macula. Laboratory mice and rats are nocturnal rodents that do not have a macula equivalent. The macula is of major importance for high acuity vision and some conditions specifically or differentially affect that retinal region compared to the peripheral retina. Macular dystrophies have been associated with mutations in a number of different genes (see [7,8] for reviews), some of which have relevant large animal models which are discussed below, including Stargardt Disease (ABCA4 mutations), Best Disease (BEST1 mutations) and in some patients with RDH5 mutations. Age-related macular degeneration (AMD) is a major cause of vision loss and has genetic and environmental contributors $[9,10]$. Screening of primate colonies for animals with lesions comparable to AMD have been performed [11] (for a review, including primate models, see Pennesi et al. [12]). The large animal model species considered here have an area centralis with high photoreceptor density, including, importantly, cones that are equivalent to the human macula [13]. While NHP also have a fovea, most of the other model species do not, although the dog has been reported to have a small concentration of cones in the center of the area centralis, referred to as a "bouquet" of cones [14].

There are several important instances where laboratory rodent engineered models fail to recapitulate the human disease; important examples including $A B C A 4$-Stargardt disease, $R D H 5$-retinopathy, or where the gene involved is not present in the mouse or rat genome e.g., EYS [15].

The disadvantages of the large animal model species tend to be cost, generation of sufficient animals due to the slower reproduction, and because of the longer lifespan (compared to laboratory rodents), the disease course may be longer.

Large animal models have also been important in therapy development. The first proof-of-concept gene augmentation therapy that eventually led to the FDA approval of the first gene therapy product, Luxturna, for the treatment of LCA due to RPE65 mutations, was performed in a dog model [16].

Table 1 shows a list of IRDs in large animal models and their identified mutations. Retinal layers and the genes discussed in detail within the text are shown in Figure 1. This review will cover the models in which the studies have contributed to the understanding of the mechanism of disease and/or protein structure and function in greater detail. 
Table 1. List of mutations in large animal models of inherited retinal disease. Detailed information for some genes (indicated with*) are displayed in the text, highlighting the role of large animal models in advancing the understanding of the disease mechanism and/or providing insights into normal protein structure and function. References are available in Supplementary Material Table S1.

\begin{tabular}{|c|c|c|c|}
\hline Mechanism & Gene & Species & Mutation \\
\hline \multirow{10}{*}{ Phototransduction } & \multirow{4}{*}{ RHO* } & $\operatorname{dog}$ & c.11C>G, p.Thr4Arg \\
\hline & & pig & p.Pro23His \\
\hline & & pig & c.1040C > T, p.Pro347Leu \\
\hline & & pig & p.Pro347Ser \\
\hline & PDE6 $A^{*}$ & $\operatorname{dog}$ & c.1939delA, p.Asn616ThrfsTer39 \\
\hline & \multirow{3}{*}{ PDE6 $B^{*}$} & \multirow{3}{*}{$\operatorname{dog}$} & c.2420G>A, p.Trp807Ter; \\
\hline & & & c.2449_2450insTGAAGTCC; p.Lys816Terfs817 \\
\hline & & & c.2404_2406delAAC, p.Asn802del \\
\hline & $P D E 6 C^{*}$ & NHP & c.1694G>A, p.Arg565Gln \\
\hline & $S A G$ & $\operatorname{dog}$ & c.1216T>C; p.Ter406extArg*25 \\
\hline \multirow{3}{*}{ Visual Cycle } & $A B C A 4^{*}$ & $\operatorname{dog}$ & c.4176insC, p.Phe1393LeufsTer3 \\
\hline & RPE65* & $\operatorname{dog}$ & c.487_490delAAGA; p.Lys154LeufsTer53 \\
\hline & RDH5* & cat & unpublished \\
\hline \multirow{8}{*}{$\begin{array}{l}\text { Channelopathies/ } \\
\text { channel related }\end{array}$} & $C N G A 1^{*}$ & $\operatorname{dog}$ & c.1752_1755delAACT, p.Thr584SerfsTer9 \\
\hline & $C N G B 1^{*}$ & $\operatorname{dog}$ & c.2387delA;2389_2390insAGCTAC, p.Ser791ArgfsTer2 \\
\hline & \multirow{4}{*}{ CNGA3* } & $\operatorname{dog}$ & c.1270C > T; p.Arg424Trp \\
\hline & & $\operatorname{dog}$ & c.1931_1933delTGG, p.Val644del \\
\hline & & sheep & p.Arg236Ter \\
\hline & & sheep & p.Gly540Ser \\
\hline & \multirow{2}{*}{$\mathrm{CNGB}^{*}$} & \multirow{2}{*}{$\operatorname{dog}$} & c.784G>A; p.Asp262Asn \\
\hline & & & CFA29:g.35,699,378-36,104,197del, c.0 \\
\hline
\end{tabular}


Table 1. Cont.

\begin{tabular}{|c|c|c|c|}
\hline Mechanism & Gene & Species & Mutation \\
\hline & $B E S T 1^{*}$ & $\operatorname{dog}$ & $\begin{array}{c}\text { c.73C }>\text { T, p.Arg25Ter; } \\
\text { c.482G }>\text { A, p.Gly161Asp; } \\
\text { c.C1388del and c.1466G }>\text { T, p.Pro463fs and p.Gly489Val }\end{array}$ \\
\hline \multirow{11}{*}{ Ciliopathies } & $B B S 4^{*}$ & $\operatorname{dog}$ & c.58A > T, p.Lys20Ter \\
\hline & $B B S 7^{*}$ & NHP & c.160delG, p.Ala54GlnfsTer18 \\
\hline & c2orf71 & $\operatorname{dog}$ & c.3149_3150insC, p.Lys1051ValfsTer91 \\
\hline & CCDC66 & $\operatorname{dog}$ & c.521_522insA, p.Asn174LysfsTer2 \\
\hline & CEP290* & cat & c.6966+9T>G, p.Ile2323AlafsTer3 \\
\hline & FAM161A & $\operatorname{dog}$ & c.1758-15_1758-16ins238, p.Ser588MetfsTer14 \\
\hline & NPHP4* & $\operatorname{dog}$ & c.462_526del, p.Leu155LysfsTer2 \\
\hline & NPHP5(IQCB1)* & $\begin{array}{l}\text { dog } \\
\text { cat }\end{array}$ & $\begin{array}{l}\text { c.952-953insC, p.Ser319IlefsTer13 } \\
\text { c.1282delCT, p.Leu428Ter }\end{array}$ \\
\hline & $R P G R^{*}$ & $\operatorname{dog}$ & $\begin{array}{c}\text { c.1084-1085delGA, } \\
\text { c.1028-1032delGAGAA } \\
\text { CFAX:g. } 33106747+190-33102324 \text { del }\end{array}$ \\
\hline & RGRIP1* & $\operatorname{dog}$ & CFA15:g.8228_8229insA29GGAAGCAACAGGATG \\
\hline & TTC8 & $\operatorname{dog}$ & c.669delA, p.Lys223ArgfsTer15 \\
\hline \multirow{2}{*}{$\begin{array}{l}\text { Photoreceptor } \\
\text { development }\end{array}$} & $C R X^{*}$ & cat & c.546delC, p.Pro185LysfsTer2 \\
\hline & STK38L* & $\operatorname{dog}$ & c.299_300ins [218;285_299]; p.Lys63_Glu103del \\
\hline
\end{tabular}


Table 1. Cont.

\begin{tabular}{|c|c|c|c|}
\hline Mechanism & Gene & Species & Mutation \\
\hline \multirow{3}{*}{$\begin{array}{l}\text { Photoreceptor to } \\
\text { Bipolar Cell }\end{array}$} & LRIT3* & $\operatorname{dog}$ & c.762_763delG, p.Lys246AsnfsTer5 \\
\hline & TRPM1* & horse & ECA1g.108,297,929_108,297,930ins1378 \\
\hline & Whippet* & $\operatorname{dog}$ & unpublished \\
\hline \multirow{8}{*}{ Structural/Other } & $A D A M 9^{*}$ & $\operatorname{dog}$ & c.1592_1881del p.Lys531AsnfsTer3 \\
\hline & AIPL1* & cat & c.577C > T, p.Arg193Ter \\
\hline & MERTK* & $\operatorname{dog}$ & CFA17:g.36338057_36338058ins[(6401);36338043-36338057] \\
\hline & $P R C D^{*}$ & $\operatorname{dog}$ & c.5G >A, p.Cys2tyr \\
\hline & $R D 3^{*}$ & $\operatorname{dog}$ & c.418_419ins[22] \\
\hline & NECAP1 & $\operatorname{dog}$ & c.544G>A, p.Gly182Arg \\
\hline & PPT1 & $\operatorname{dog}$ & $\begin{array}{c}\text { CFA15:g.[2,866,454_2,877,574dup; } \\
\text { 2,874,661_2,875,048con2,877,563-2,877,607inv] }\end{array}$ \\
\hline & $S L C 4 A 3$ & $\operatorname{dog}$ & c.2601_2602insC, p.Glu868ArgfsTer104 \\
\hline
\end{tabular}




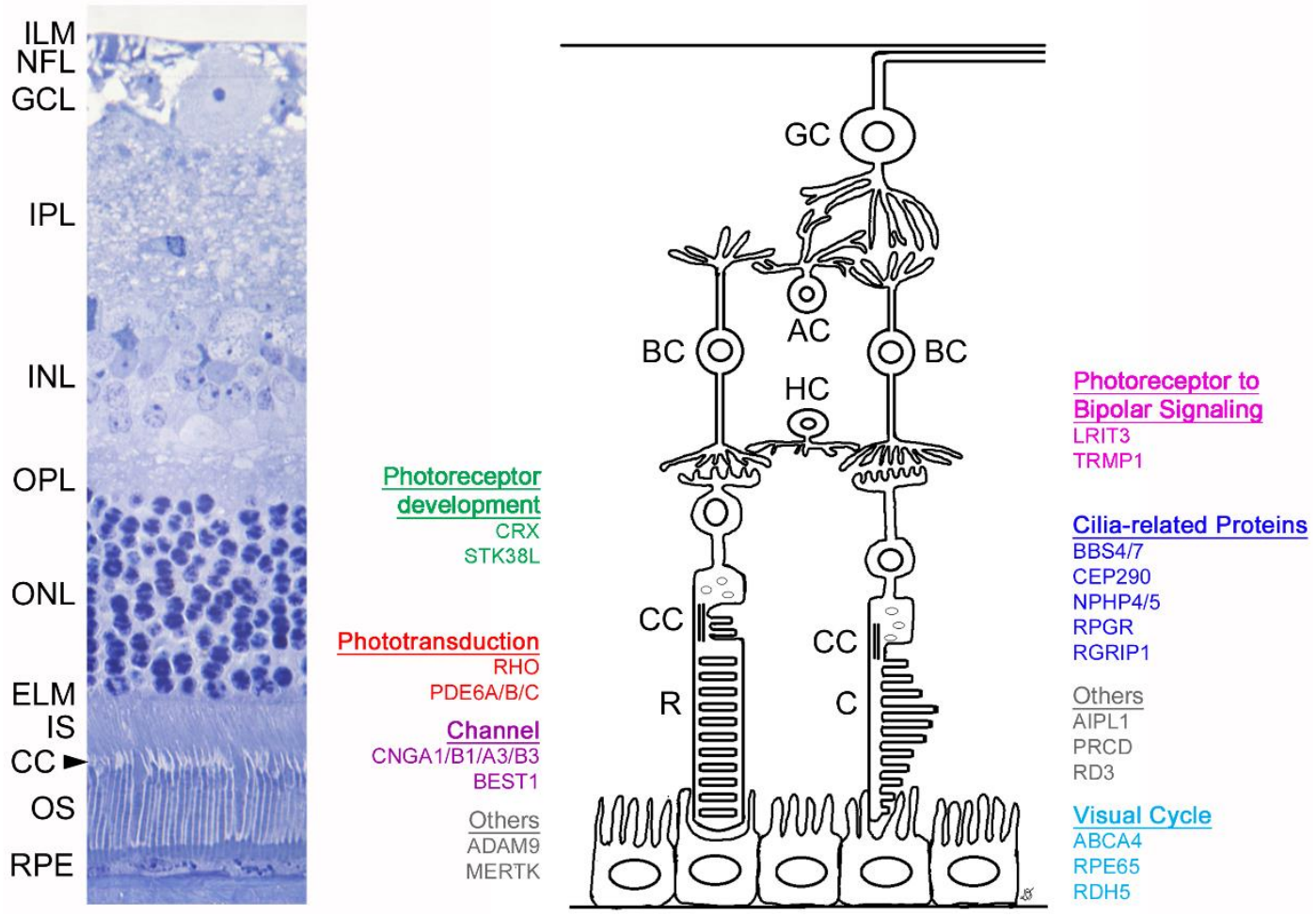

Figure 1. Schematic of retinal layers and associated genes discussed within this review. The left image shows a histologic section of a feline retina (with comparable anatomy to the human retina). The right panel depicts a schematic showing the genes detailed in this review and their site of expression, grouped per biological process. Inner limiting membrane (ILM), nerve fiber layer (NFL), ganglion cell layer (GCL), inner plexiform layer (IPL), inner nuclear layer (INL), outer plexifom layer (OPL), outer nuclear layer (ONL), external limiting membrane (ELM), photoreceptor inner segment (IS), connecting cilium (CC), photoreceptor outer segment (OS), retinal pigmentary epithelium (RPE). Ganglion cell $(\mathrm{GC})$, amacrine cell (AC), bipolar cell (BC), horizontal cell (HC), rod (R), cone (C).

\section{Mutations in Phototransduction Genes}

There are spontaneously occurring large animal models with mutations in the genes of the phototransduction cascade, and rhodopsin (RHO) transgenic pig models have been generated. Studies of these models have contributed to the understanding of how the mutation of these genes leads to photoreceptor death.

\section{1. $R H O$}

Mutations in $R H O$ can result in a range of phenotypes, most commonly autosomal dominant $\mathrm{RP}$ (adRP), but also autosomal recessive RP (arRP) and congenital stationary night blindness (CSNB). Animal models and in vitro studies have allowed $R H O$ mutations to be divided into seven classes (see [17] for a recent review).

\subsubsection{Dog Model}

A spontaneous dog model of $R H O$ adRP has been identified [18]. The c.11C $>\mathrm{G}, \mathrm{p}$.Thr4Arg mutant $\operatorname{dog}\left(R h o^{T 4 R}\right)$ develops a retinal degeneration that is greatly exacerbated by light exposure [19]. The phenotype of this dog model closely resembles that of the human p.Thr4Lys RHO mutation which results in dominant RP [20]. Studies of the $R h o^{T 4 R}$ dog have advanced the understanding of the disease mechanism underlying class four $R H O$ mutations (those with altered post-translational modification and stability [17]). 
RHO has seven transmembrane loops with intradiscal and cytoplasmic loops and in the dark-adapted state is combined with the chromophore 11-cis-retinal. The N-terminal of the protein, which is affected by the p.Thr4Lys mutation, is positioned within the lumen of the outer segment discs and creates a "cap" over one of the extracellular loops. This cap contributes towards thermal stability and receptor activation of the protein; it also protects the chromophore to opsin protein covalent bond from hydrolysis. Important for the cap role of the N-terminal is glycosylation at N2 and N15. The p.Thr4Arg mutation interferes with glycosylation at the N2 site, altering the cap role. The monoglycosylated rhodopsin is expressed and is trafficked to the outer segment; however, it loses the chromophore faster than the normal meta-rhodopsin II and interacts poorly with the G-protein [21]. The $R h o^{T 4 R}$ dog has light dependent degeneration similar to the sector RP seen with some rhodopsin mutations. In sector RP, the inferior retina is more severely affected as this region gets more light exposure [22]. There is increasing awareness of the need to reduce light exposure to patients with certain RHO mutations [23]. Studies suggested that the unliganded form of the mutant opsin has a detrimental effect because of the loss of its structural integrity. Further evidence to support this was provided by cross breeding $R h o^{T 4 R}$ dogs with the Rpe $65^{-/-}$dog to produce $R h o^{T 4 R /+} R p e 65^{-/}$ dogs which lack 11-cis-retinal chromophore (due to the lack of Rpe65 function) and thus have only unliganded mutant rod opsin (i.e., have a lack of rod opsin combined with 11-cis-retinal) and show a greatly accelerated rate of retinal degeneration compared to $R h o^{T 4 R /+} R p e 65^{+/+}$dogs (see details on the Rpe65 ${ }^{-/}$dog below) [21].

\subsubsection{Pig Models}

A number of Rho transgenic pigs have been generated, representing different human mutations: p.Pro23His [24], p.Pro347Leu [25] and p.Pro347Ser [26]. Studies using the p.Pro347Leu pigs showed the development of ectopic cone to rod bipolar cell synapses [27] and also interference with the cone to OFF-bipolar cell connection maturation [28]. The potential contribution of oxidative stress to cone death was demonstrated in the model [29]. The light responses of single rod photoreceptors of p.Pro347Leu and p.Pro347Ser transgenic pigs have been studied by suction pipette recording. The recording revealed protracted recovery of the photoresponse and a progressive reduction in the time to peak of the response with reduced sensitivity. This work suggests that the mutant rhodopsin reaches the outer segment and that the substitution at Pro347 interferes with inactivation of the activated form of Rho. The resulting hypothesis was that the carboxyl end of Rho may be involved in the binding of rhodopsin kinase. Mutations at Pro347 may reduce the stability of the carboxyl end attachment to rhodopsin kinase, potentially slowing phosphorylation and the subsequent binding of arrestin [30].

The p.Pro23His pig model has been used to study factors associated with cones developing dormancy and whether they can be reactivated. There are stages of retinal degeneration where the degenerating cones lose inner and outer segments. The remaining cell bodies are described as dormant cones. One hypothesis is that a lack of glucose supply to the cones as a result of loss of surrounding rods leads to cone dormancy. Experiments to either introduce rod precursors or to supply glucose to the subretinal space resulted in reactivation of the dormant cones suggesting mechanisms for the treatment of later-stage IRDs [31].

\subsection{Phosphodiesterase 6 Genes}

Mutations in genes encoding for the subunits forming the rod specific cyclic guanosine monophosphate (cGMP) phosphodiesterase (PDE) holoenzyme cause about 36,000 cases of autosomal recessive RP worldwide in humans, leading to the early onset of night blindness and retinal degeneration [32].

The rod PDE heteromeric holoenzyme has a catalytic core made of PDE6A and PDE6B subunits combined with two inhibitory gamma subunits [33]. Mutation in the gene encoding the alpha subunit of cGMP-PDE (Pde6a) causes PRA in the Cardigan Welsh corgi dog [34,35] and is a model of RP43 in humans, which accounts for $3 \%$ to $4 \%$ of recessive RP in North America [36,37]. Mutations in the gene 
encoding the beta subunit of cGMP-PDE (Pde6b) have been identified in a few dog breeds (see below), including the Irish setter dog [38], which is a model for RP40 in humans and represents about 3\% to 5\% of the recessive forms of RP $[39,40]$. Disease mechanisms for these canine models are detailed below.

\subsubsection{PDE6A}

A dog model with a null mutation in the gene encoding for Pde6a has been identified. It has a relatively severe phenotype and is a model for RP43 in humans [34,35]. This form of PRA was given the name rod-cone dysplasia type 3 (rcd3). The frameshift mutation, c.1939delA. p.Asn616ThrfsTer39, results in the absence of Pde6a in the affected dog retina (Pde6a $\left.{ }^{-/}\right)$[35]. Western blot analysis shows the absence of all Pde6 subunits, showing the requirement of Pde6a for stability and normal trafficking of Pde6b [35]. In the absence of the Pde6 holoenzyme, the cGMP hydrolyzing activity is absent and cGMP accumulates in the rod photoreceptors [41]. Increased cGMP is a well-established cause of photoreceptor cell death, likely due to the increased influx of calcium ions into the outer segment [42], triggering apoptosis [43]. The rod outer segments fail to mature in Pde6a $a^{-/}$dogs and the genetically unaffected cones have stunted outer segments, which is reflected in a reduction in cone electroretinogram (ERG) a-waves early in the disease process [35]. Following the death of rod photoreceptors, there is a progressive loss of cones, which is reflected in the declining cone ERG amplitudes which eventually become undetectable at about one year of age (SMPJ unpublished data). Adeno-associated gene therapy was able to rescue rod function and promote cone function, as well as preserve retinal morphology $[41,44]$.

\subsubsection{PDE6B}

The catalytic beta subunit (PDE6B) of the cGMP-PDE heteromeric holoenzyme is another essential component of the rod photoreceptor phototransduction cascade located in the outer segments [33]. Mutations in the gene encoding for Pde6b causes PRA (rod-cone dysplasia type 1, rcd1) in the Irish Setter dog $[38,45,46]$ which is a model for RP40 in humans. RP40 is one of the most common autosomal recessive RPs leading to blindness in midlife in humans. As with the Pde $6 a^{-/-} \mathrm{dog}, \operatorname{rod}$ photoreceptors are affected first, then cones later in the disease $[47,48]$. The $P d e 6 b^{-/}$dog phenotype has an autosomal recessive mode of inheritance and is caused by a nonsense mutation (c.2420G>A, p.Trp807Ter) [38,45]. This truncated protein would lack the C-terminal domain that is required for posttranslational processing and membrane association. The failure of phosphodiesterase activity due to a lack of function in Pde6b leads to elevated cGMP levels from an early age [47,49]. The elevation of cGMP in rods as they develop outer segments results in the halting of outer segment elongation followed by rod degeneration, starting in the central retina first, then spreading to the entire retina following the same pattern of rod maturation. The cone outer segment development is also halted and, with the loss of the rods, the genetically unaffected cone photoreceptors also progressively degenerate $[46,47]$. Interestingly, in contrast to the $P d e 6 a^{-/}$dog retina where the lack of Pde6a leads to the absence of both alpha and beta Pde6 subunits, the Pde6 $b^{-/}$dog retina has a detectable Pde6a subunit in Western blot, prior to rod degeneration [38]. Therefore, it appears that the alpha subunit is necessary for the beta subunit to be maintained, while the beta subunit is not essential for the maintenance of the alpha subunit. Adeno-associated gene therapy has been shown to halt retinal degeneration in the $r c d 1$ dog [50].

Mutations in $P d e 6 b$ have been identified in at least two other breeds of dogs (Sloughi and American Staffordshire terriers; see Table 1 for mutation information) $[51,52]$.

\subsubsection{PDE6C}

Recently, a NHP spontaneous achromatopsia model was identified with a missense mutation in a cone phosphodiesterase subunit gene (Pde6c; c.1694G>A, p.Arg565Gln) [4]. Affected animals had behavioral changes, reflecting the photophobia seen in human subjects. They also had macula changes including foveal thinning and a subtle bullseye maculopathy. In vitro studies suggested that 
the mutant protein was expressed and colocalized with its chaperones, Aipl1 and P. However, the mutation alters the catalytic domain, meaning that the mutant protein fails to hydrolyze cGMP.

\section{Visual Cycle}

\section{1. $A B C A 4$}

Stargardt disease is an inherited macular dystrophy which affects one in 8,000-10,000 people. It is the most common inherited macular dystrophy and there is currently no cure. It results from mutations in the gene $A B C A 4$. Mutations in $A B C A 4$ also result in cone-rod dystrophies and RP. ABCA4 is an ATP-dependent flippase expressed in the photoreceptor disc membrane and is necessary in the visual cycle for its transport of N-retinylidene-phosphatidylethanolamine and phosphatidylethanolamine out of the lumen into the cytoplasm [53].

A 1 bp insertion in Abca4 was identified in a family group of Labrador retriever dogs resulting in a frameshift and premature stop codon [54]. This mutation causes a decrease in the mRNA transcript and the loss of the full-length protein. As seen in humans, there is an accumulation of lipofuscin in the RPE cells. Cone and rod photoreceptors both had abnormal function and were decreased in number in older affected dogs (10+ years). The development of a colony of these dogs as a model for therapy will have a substantial impact on the treatment of humans with Stargardt disease because mouse $\mathrm{Abca4^{-/- }}$ models lack a phenotype $[54,55]$. The phenotype in the dog appears to be milder than that seen in human subjects, with $A B C A 4$ mutations reflecting species differences [56]. Early biomarkers of retinal changes in the affected dogs will facilitate the use of the Abca4 mutant dog as a model for human Stargardt disease.

\subsection{RPE65}

Large animal models with visual cycle gene mutations include the Rpe $65^{-/-}$dog. This is a model for LCA2. This model was crucial in the development of translational gene augmentation therapy which led to the first FDA-approved gene therapy product. The first animal injected with a therapeutic vector for LCA2 was an Rpe $65^{-/-}$dog. Therapies were developed by three independent groups and consisted in each instance of recombinant adeno-associated virus vectors packaged with RPE65 cDNA. The precise details of promoters and other features such as polyadenylation signals and enhancers differed between the groups. Four groups with colonies of Rpe $65^{-/-}$dogs reported successful restoration of rod and cone function [16,57-59]. Loss of rod photoreceptors in the Rpe65 $5^{--}$dog was slow and gene therapy showed ERG rescue even in middle-age [60]. Studies showed that S-cones were sensitive to the lack of normal 11-cis-retinal supply and s-cone opsin immunoreactivity was lost at an early age [61]. There were some phenotypic differences between the Rpe65 $5^{-/}$dog colonies, with one showing early photoreceptor degeneration in the area centralis (canine equivalent of the human macula) [62]. Trials in human subjects have not resulted in the same restoration of function shown by the dramatic improvement in ERG responses seen in dog and mouse models. A possible explanation for this species difference in therapy efficacy was provided by a comparison of the Rpe65 function of primates and dogs. This suggested that primates require a higher level of Rpe65 than dogs for the function of the visual cycle and that the current therapy might not result in adequate levels of enzymatic function in humans [63].

\section{3. $\mathrm{RDH5}$}

Recently, a cat model with a mutation in another visual cycle gene, $R d h 5$, has been identified by our group [64]. Rdh5 functions to convert 11-cis-retinol to 11-cis-retinal for transport to photoreceptors for reforming the visual pigments. In humans, $\mathrm{RDH} 5$ mutations cause a variety of phenotypes. Fundus albipuncatatus is the predominant phenotype [65] but a subset of patients have macular atrophy [66-69] or cone dystrophy [70]. The Rdh5-mutant cat promises to be a valuable model because the $R d h 5^{-/-}$ mouse lacks a phenotype and does not recapitulate RDH5-retinopathy in human patients [71]. In 
contrast, the cat model, similar to affected humans, shows a very delayed recovery of photoreceptor function following light exposure and recapitulates the RDH5-macular atrophy phenotype.

\section{Channelopathies/Channel-Related Mutations}

Mutations that affect channel protein structure and function resulting in disease are termed channelopathies. Spontaneously occurring retinal channelopathies have been identified in dogs resulting from mutations in the cyclic nucleotide-gated ion channels (CNG) of the rod and cone photoreceptors and the anion channel bestrophin 1 (BEST1).

CNG channels in the rod and cone photoreceptors are directly involved in phototransduction. The CNG channels expressed in the rod photoreceptor consist of four subunits: three CNGA1 and one CNGB1 [72-74]. The CNG channel in cone photoreceptors consists of CNGA3 and CNGB3 proteins, in a 3:1 or 2:2 ratio (the stoichiometry of the CNGA3/CNGB3 channel is under debate) [72]. Damaging mutations in the rod CNG channels result in RP, while mutations in cone CNG channels result in achromatopsia.

BEST1 is a homopentameric channel expressed in the retinal pigment epithelium (RPE) and involved in anion transport and intracellular calcium homeostasis [75]. Mutations in BEST1 result in a collection of retinal diseases. Mutations in BEST1 often result in Best Vitelliform Macular Dystrophy, but the age of onset, mode of inheritance, disease characteristics and prognosis can vary [75].

\subsection{CNGA1}

In humans, damaging mutations in CNGA1 result in RP49 representing $1 \%$ or less of arRP cases [39]. A 4 bp deletion in Cnga1 was identified in Shetland Sheepdogs with PRA. The mutation causes a frameshift and a premature stop codon in a highly conserved region of the protein [76].

\section{2. $C N G B 1$}

There are three splice variants of CNGB1 expressed in the retina, glutamic acid rich proteins (GARPs) GARP1, GARP2 and CNGB1a. The full-length protein, CNGB1a, is part of the heterotetrameric CNG channel of the rod photoreceptor [72]. A complex mutation in Cngb1 was identified in Papillon dogs with PRA. The mutation identified in these dogs is a 6 bp insertion accompanied by a 1 bp deletion, predicted to result in a frameshift and a premature stop codon, six amino acids downstream [77]. Upon further analysis of the Cngb1a transcript in the $\mathrm{Cngb1}^{-/}$dogs, it was found that the mutation led to the skipping of exon 26, resulting in a premature stop codon early in exon 27. A truncated Cngb1a protein is produced, but does not form channels with Cnga1 and remains in the inner segments of the rod photoreceptors [78]. Mutations in CNGB1 cause RP45 in humans, which represents less than $4 \%$ of arRP cases [39].

Human RP45 patients with mutations downstream of the GARP splice variants, the mouse knockout model (Cngb1-X26) and the $\mathrm{Cngb1}^{-/}$dog have similar phenotypes [78,79]. The canine model shows a slow loss of rod photoreceptors and the relative preservation of cones, particularly in the area centralis and visual streak. Cone function decreases as the disease progresses, as assessed by ERG, but cone-led vision remains normal, at least up to four years [77]. Preliminary gene therapy trials have shown that treatment at 3.5-6.5 months of age in affected dogs rescues vision and slows the progression of the disease in the treated areas [78].

Both the slow disease progression and the large treatment window (in dogs and anticipated in humans [80]) make the $\mathrm{Cngb1}^{-/-}$dog an ideal model for studying therapies and outcome measures.

\section{3. $C N G A 3$}

About $25 \%$ of human achromatopsia cases are caused by damaging mutations in the alpha subunit of the cone CNG channel (CNGA3) [81]. Two canine models of achromatopsia were identified with mutations in CNGA3. The mutations, p.Arg424Trp and p.Val644del (R424W and V644del, respectively), provided intriguing mutation sites for in vitro testing. Modeling of these mutations lead to further 
insights into CNG channel gating and subunit interactions [82]. The residue R424 is located in the S6 transmembrane helix and forms a salt bridge with the residue E306 in the S4-S5 linker. Protein modeling of the canine R424W mutation found the disruption of this salt bridge plays an important role in protein folding, subunit assembly and channel gating. In vitro expression studies of the R424W mutation showed increased mislocalization of the mutant CNGA3 protein and the mutant channels did not produce cyclic nucleotide-activated currents [82].

The canine V644del mutation is in the C-terminal leucine zipper (CLZ) domain, which is involved in channel assembly and stability. The one amino acid deletion shifts all subsequent residue interactions within the domain. In vitro studies in a heterologous expression system showed evidence of mislocalization and a decrease in the total number of active channels, but some mutant channels $(\sim 60 \%)$ reached the cell membrane and had normal cyclic nucleotide-activated currents [82].

Two spontaneous sheep models of Cnga3 achromatopsia have been identified [83]. The first identified has a nonsense mutation (p.Arg236Ter) and the second a missense mutation (p.Gly540Ser) [84]. Adeno-associated virus gene therapy was able to restore cone function in both models $[84,85]$.

\subsection{CNGB3}

Two unique mutations were identified in the canine $\mathrm{Cngb3}$ gene-a genomic deletion that removes the entire $\mathrm{Cngb3}$ gene ( $\mathrm{Cngb3}^{--}$) and a missense mutation (p. Asp262Asn; D262N). The missense mutation was identified in German Shorthaired Pointers, while the genomic deletion was initially found in Alaskan Malamutes and later found in other breeds [86,87]. Mutations in CNGB3 are responsible for at least $50 \%$ of achromatopsia cases in humans, making it an ideal target for therapies [87,88].

The D262N mutation in Cngb3 inspired investigation into the Tri-Asp motif that is conserved in CNG channels [89]. When this mutation was introduced to heterologously expressed CNGA3, it abolished homomeric channel function and was responsible for mislocalization of the protein. When the mutation was introduced in CNGB3 in coexpression studies with CNGA3, the response to cyclic nucleotides was reduced but still present and consistent with CNGA3 homomeric channel function. These experiments show the Tri-Asp motif is necessary for proper cone CNG channel formation, but raises the question why mutations in CNGB3 result in the loss of cone function and achromatopsia when CNGA3 can form a functioning homomeric channel in the absence of CNGB3. Further work in retinal tissue and/or cone photoreceptors will be needed to elucidate this [89].

Delivery of a human CNGB3 gene via rAAV5 vector to both $\mathrm{Cngb3}^{-/}$and the D262N mutant dogs showed that the vector could be targeted to the medium and long wavelength $(\mathrm{M} / \mathrm{L})$ cones via a human red cone opsin promoter and the rescue was dependent on the age of the dog and the promotor, not on the mutation type [90].

\subsection{BEST1}

Best vitelliform macular dystrophy (Best disease, BVMD) has autosomal dominant inheritance and is the most common disease associated with mutations in the gene BEST1. Four other disease phenotypes have been described in association with BEST1 mutations: adult onset vitelliform macular dystrophy, autosomal recessive bestrophinopathy, autosomal dominant vitreoretinochoroidopathy and retinitis pigmentosa. BVMD is characterized by at least one vitelliform lesion in the macula but can present with multiple lesions. The disease slowly progresses to degenerate the RPE and retina in the affected regions, resulting in vision impairment [75]. In dogs, a similar disease has been described, termed canine multifocal retinopathy (CMR) and is caused by mutations in the Best1 gene. In contrast to the BVMD in humans, CMR due to Best1 mutations is an autosomal recessive disease and has a consistent and predictable disease phenotype. This consistency and the detailed natural history of the disease lends well to measuring the outcomes of translatable therapies.

Initially, two Best1 mutations were identified in dogs: p.Arg25Ter (Great Pyrenees and mastiff-related breeds, $c m r 1$ ) and p.Gly161Asp (Coton de Tulear, $c m r 2)$, with the former resulting in a premature stop codon and, presumably, a lack of Best1 protein [91]. Analysis of additional breeds 
with CMR identified another breed (Lapponian herder, $c m r 3$ ) with two deleterious mutations in exon 10, a $1 \mathrm{bp}$ deletion leading to a frameshift and premature stop codon (p.Pro463fs) and a missense mutation (p.Gly489Val) [92]. Interestingly, the phenotype resulting from the three mutations in dogs is indistinguishable. The dogs present with multifocal regions of retinal separation with a pink or tan-colored subretinal fluid, which eventually leads to retinal degeneration. Using optical coherence tomography to image eyes from $c m r 1 / c m r 1, c m r 3 / c m r 3$ and $c m r 1 / c m r 3$ dogs in vivo, the earliest detectable sign of the disease is at $\sim 11$ weeks of age in which there is a retinal elevation in the fovea-like region of the area centralis. As the disease progresses, this retinal elevation becomes a macrodetachment, surrounded by microdetachments. Rates of progression, detachment location and number varied, but the disease was typically localized to the more cone-rich regions of the retina [93].

Immunohistochemistry of CMR canine tissues showed a lack of RPE apical microvilli at the cone photoreceptor/RPE interface along with accumulated lipofuscin within the RPE. The loss of the RPE apical processes results in a loss of all direct contact of the cones to the RPE, severely impacting the physiological role the RPE has on retinal maintenance. It is hypothesized that the lack of RPE apical processes and subsequent weakened interphotoreceptor matrix is instrumental in the characteristic detachments and lesions observed in diseases caused by BEST1 mutations [93,94]. Interestingly, microdetachments were identified in response to light exposure in pre-clinical CMR dogs. The detachments occurred between the photoreceptor inner/outer segments and the RPE/tapetum interface. These light-induced detachments occurred within minutes and increased in response to time of light exposure and would resolve within $24 \mathrm{~h}$.

Using a rAAV2 vector delivered subretinally, CMR dogs were treated by gene augmentation with wildtype canine or human BEST1. Macro and microdetachments were resolved and RPE microvilli ensheathment of cone photoreceptors returned within the treatment area. This positive outcome was retained in the dogs for as long as 207 weeks post injection. The same outcome was present regardless of age of treatment (within 27-69 weeks of age), the stage of detachments or mutation (cmr1/cmr1, $\mathrm{cmr} 3 / \mathrm{cmr} 3$ or $\mathrm{cmr} 1 / \mathrm{cmr} 3$ ). These results show promise for the treatment of human patients with BEST1 mutations [93].

\section{Cilia-Related Proteins (Ciliopathies)}

Photoreceptors are non-motile sensory ciliated cells. The connecting cilium between inner and outer segment is critical for the transport of proteins to and from the outer segment. Many proteins are expressed in this region of photoreceptors and act to control the trafficking of proteins. Ciliopathies is a general term used to group conditions resulting from mutations in cilia proteins. As cilia are present in many cell types, mutations in cilia proteins can cause syndromic disease where retinal degeneration is present, accompanied by disorders in other organ systems. Mutations that have a milder effect on function may result in a photoreceptor-only phenotype such as LCA or RP. A number of large animal models with mutations in cilia related genes have been identified (Table 1).

\subsection{BBS4}

A mutation in the Bbs4, (Bardet-Biedl syndrome 4) gene, was identified in Hungarian Puli dogs with PRA. This mutation (c.58A $>$ T, p.Lys20Ter) is predicted to result in nonsense mediated decay of the Bbs4 transcript. BBS4 is one of the BBS genes involved in cilia function. These dogs showed a typical PRA phenotype along with noted obesity and abnormal sperm, although more affected dogs may need to be examined before confirming that this is a syndromic BBS model [95].

\subsection{BBS7}

An NHP model of Bardet-Biedl syndrome has been recently described. A mutation in exon 3 of the $B b s 7$ gene c.160delG (p.Ala54GlnfsTer18) that is predicted to produce a truncated non-functional protein was identified. As with BBS4, BBS7 is involved in cilia function. Typically in humans, mutations in BBS genes cause a syndromic condition. The affected NHPs had several features of BBS, including 
retinal atrophy, which was most severe centrally; the affected animals had smaller brains, renal disease, and the males had small testes. This is the first described model of BBS in NHP and shares many characteristics with BBS patients with truncating mutations [3].

\subsection{CEP290}

This cat model, $r d A c$ (retinal degeneration, Abyssinian cat) has been studied in detail for many years. Compared to most CEP290 (centrosomal protein 290) mutations in other species, the cat model has a mild phenotype. The onset and rate of photoreceptor degeneration in the cat with the sparing of the area centralis makes it a model for RP [96,97]. In humans, CEP290 mutations can result in a spectrum of phenotypes including lethality, severe syndromic disease (e.g., Joubert syndrome) and most commonly LCA; see [98] for a review. Milder phenotypes such as RP are less common. In the cat, an intronic mutation (c.6966+9T>G) leads to the introduction of a stronger splice acceptor site (the wildtype splice acceptor is a GC rather than the much more commonly used GT). The mutation strengthens an adjacent GT, which, when used, adds 4 bps to the exon 50 sequence, the resulting frameshift introduces a premature stop codon [99]. The truncated protein escapes nonsense mediated decay and is expressed. In addition, the wildtype acceptor site is still used for a percentage of the transcripts (unpublished data). The combination of a truncated protein with some remaining function combined with a low-level production of full-length transcripts explains the mild phenotype. CEP290 is too large to be packaged in an adeno-associated virus vector and one therapeutic approach being investigated is the use of a truncated transcript so that a miniprotein may have partial function and convert a severe phenotype into a milder phenotype similar to that of the cat.

\subsection{NPHP4}

Wire-haired dachshunds have a cone-rod dystrophy resulting from a truncating mutation in Nphp4. The identified Nphp4 mutation was a deletion involving exon 5/intron 5 that led to skipping of exon 5 and a premature truncation in exon 6 of 30 (c.462_526del, p.Leu155LysfsTer2) [100]. A colony was established from a single founder male [101]. Puppies had miotic pupils and cone-mediated ERGs were reduced prior to retinal maturation. Furthermore, they did not show the normal increase in amplitudes with retinal maturation and further declined in amplitude rapidly. The amplitudes of the rod-driven responses were less severely affected, but were lost with age [102,103]. Interestingly, the condition is non-syndromic in dogs, just presenting as a cone-rod dystrophy. Human patients with NPHP4 mutations do not always develop a retinal phenotype, but typically have nephronophthisis, with some patients having Senior-Løken syndrome, which combines the renal phenotype with a retinal dystrophy (see for [104] a review). This phenotype difference may represent a species difference, with Nphp4 $4^{-/}$mice also only having an ocular phenotype with no renal abnormalities, but also showing male infertility [105].

\subsection{NPHP5 (IQCB1)}

A mutation was identified in the NPHP5 gene (aka IQCB1) resulting in a cone-rod dystrophy in American pit bull terrier dogs (crd2) modeling non-syndromic LCA. This mutation (c.952-953insC, p.Ser319IlefsTer13) results in a frameshift and a premature stop codon [52]. At 6 weeks of age, the $c r d 2$ dogs had no cone function and abnormal rod function. Morphologically, the cones completely lacked outer segments, while the rods developed disorganized outer segments. Despite the lack of cone function, the cones are retained within the central retina up to 33 weeks of age [106]. Adeno-associated gene therapy restores and improves photoreceptor function and preserves the outer retina layer [107].

\subsection{RPGR}

Retinitis pigmentosa GTPase regulator (RPGR) localizes to the connecting cilium and mutations within the RPGR gene account for $>80 \%$ of X-linked RP (XLRP). There are two major retinal isoforms, one encoded by exons 1-19 and a second isoform that consists of exons 1-15 and a retained portion of intron 
15 (ORF15; see [108] for a summary). ORF15 is a mutation hotspot [109]. Three different Rpgr mutations cause $\mathrm{X}$-linked retinal degeneration in dogs. One is caused by a genomic deletion [110] and two are due to microdeletions in ORF15 and provide two distinct mechanistic models for RPGR-XLRP [111]. The first, known in the dog as XLPRA1, has a 5 bp deletion and a premature stop codon [111]. This is a relatively late onset and slowly progressive degeneration [112]. The second form, XLPRA2, has a 2 bp deletion with a frameshift resulting in the addition of 34 basic residues. In vitro studies showed that the mutant protein aggregated in the endoplasmic reticulum and is hypothesized to have a toxic effect [111]. The phenotype presents as an early onset degeneration with early changes being outer segment disruption and opsin (rod and cone) mislocalization. Photoreceptor cell death was shown to occur in a biphasic manner with two distinct phases of cell death with evidence of remodeling occurring [113]. Studies of the heterozygous females revealed that there are patches of diseased retina, presumably resulting from regions where random $\mathrm{X}$-inactivation has resulted in expression of the mutant allele and patches of unaffected retina (where the wildtype allele is expressed). In the earlier onset XLPRA2 migration of adjacent photoreceptors into regions where rod photoreceptors died occurs, showing retinal plasticity in the younger animals. This remodeling was not described in the XLPRA1, where patches of degeneration occur at a later age [114].

\subsection{RPGRIP1}

Retinitis pigmentosa GTPase regulator-interacting protein 1 (RPGRIP1) localizes to the connecting cilium, where it interacts with RPGR. Mutations in RPGRIP1 are associated with autosomal recessive LCA. A cone-rod dystrophy form of PRA in a colony of miniature longhaired Dachshunds was reported to be due to an insertion in Rpgrip1 [115] and the rescue of the phenotype by gene therapy was achieved [116]. When miniature longhaired Dachshunds in pet homes were investigated, the Rpgrip1 insertion did not appear to segregate with disease status [117]. Further studies have shown that two other loci influence the development of the phenotype [118-120]. This is an example of the potential effect of modifying loci on phenotype.

\section{Photoreceptor Development}

\section{1. $C R X$}

The CRX gene encodes an OTX-like homeodomain transcription factor which is essential for photoreceptor development, maturation and survival [121-124]. Transcription factors are essential for control of the maturation of progenitor cells [123-126]. Only one spontaneously occurring large animal model of a retinal transcription factor homeobox mutation has been described, the $C r x^{R d y}$ cat $[127,128]$. The heterozygous animal has a severe phenotype of cone-led retinal dystrophy and is a model for one form of severe early childhood onset blindness (LCA7). While most mutations in CRX result in LCA7, other phenotypes including cone-rod dystrophy, RP and macular degeneration have been described [129-131]. CRX mutations have been reported to account for between $0.6 \%$ and $2.35 \%$ of LCA [131-134].

As with other transcription factors, CRX has a characteristic structure with a DNA binding domain (homeodomain) near its N-terminal and a transactivation domain at the C-terminal. The $C r x^{R d y /+}$ mutant cat models Class III CRX mutations, which are antimorphic frameshift/nonsense mutations with intact DNA binding, but a lack of target gene transactivation [135]. The $C r x^{R d y /+}$ cat mutation is caused by a 1 bp deletion (c.546delC; p.Pro185LysfsTer2) in the final exon of the $C r x$ gene [127]. This mutant mRNA avoids nonsense mediated decay and produces a truncated Crx protein with an intact DNA-binding domain but disrupted transactivation domain [128]. Both the mutant transcript and protein accumulate at higher levels than the wildtype versions, possibly due to increased stability of the mutant mRNA compared to the wildtype. In vitro studies showed that the mutant mRNA fails to activate its own promoter [128]. This suggests that the mutant protein has a dominant negative effect by binding promoter recognition sites, but fails in its transactivation function. The result is 
misregulated gene expression; for example, Rho and cone arrestin (Arr3) mRNA levels are severely decreased. Truncated photoreceptor outer segments are produced, but the photoreceptors fail to fully mature [128]. A decreased rod ERG is detectable, which shows evidence of partial maturation before this is halted and the ERG amplitudes decline, paralleling rod degeneration. Cone function is more severely affected, with no cone ERG responses being detectable [128].

\subsection{STK38L}

An early retinal degeneration was described in Norwegian Elkhounds in 1987 [136] in which the dogs present with vision impairment in low light as early as 6 weeks of age. The causal mutation was found to be a short interspersed element (SINE) insertion in exon 4 of $S t k 38 l$, a gene that had not been associated with retinal degenerations before its discovery in the Norwegian Elkhounds [137]. The mRNA transcript is produced in the affected dog but does not contain exon 4 . Interestingly, at $\sim 6$ weeks of age, the expression of the mutant $S t k 38 l$ transcript is similar to control dogs, but expression increases at $\sim 8$ and $\sim 12$ weeks [138].

Detailed histological experiments were performed on affected canine retina to understand the role of Stk381 in retinal development and how the lack of the functional protein results in retinal degeneration. The retina in $\sim 4$ week old Stk38l-affected dogs is normal, but by $\sim 8$ weeks of age the rod photoreceptors begin to show mislocalization of Rho, irregularities in the outer segments and increased TUNEL labeling. However, this increase in apoptotic cells is not accompanied by a thinning of the outer nuclear layer (ONL), as would be expected from loss of rod photoreceptors. The maintenance of ONL thickness is a result of proliferation of rod-like photoreceptors which express both Rho and cone S-opsin. After $\sim 14$ weeks of age, this proliferation ceases and the ONL begins to thin as the photoreceptors die, resulting in the loss of at least $50 \%$ of the ONL rows by 48 weeks [138].

The Stk38l-affected dogs provide an interesting and unique model of retinal degeneration in which differentiated photoreceptors either apoptose or proliferate for a short amount of time before retinal degeneration progresses.

\section{Photoreceptor to Bipolar Cell Signaling}

\subsection{LRIT3}

Recently, a dog model of recessively inherited CSNB has been identified due to a mutation in leucine-rich-repeat, immunoglobulin-like transmembrane-domain 3 gene (LRIT3). Mutations in LRIT3 in humans causes a form of CSNB [139]. The ERG of the affected dogs shows a lack of ON-bipolar cell function with preservation of cone OFF-bipolar contributions [140-142]. There is currently debate about the positioning of the LRIT3 protein which had been described as being in the synaptic tips of the bipolar cells; however, a recent publication showed that it was presynaptic, being present in photoreceptors, but bridged the synapse to influence the positioning of post-synaptic glutamate signaling proteins [143]. The new availability of a large animal model may facilitate further investigations.

\subsection{TRPM1}

Studies of Appaloosa horses with CSNB contributed to the identification of the role of transient receptor potential cation channel subfamily $\mathrm{M}$, member 1 (Trpm1) in bipolar cell signaling [144,145]. The night-blind Appaloosa horse was first recognized as an animal model for the Schubert-Bornschein type of CSNB in the 1970s [146]. The study published at that time reported a lack of an ERG b-wave and night blindness but no retinal degeneration or obvious morphological abnormality of the photoreceptor synapses with second order neurons [146]. The correlation of CSNB in the Appaloosa with the Leopard complex spotting coat color was recognized [147]. This coat color is governed at a single gene locus with animals homozygous for the Leopard complex spotting associated allele (LP) also having CSNB [147]. When the LP locus was mapped, Trpm1, which is also expressed in melanocytes, was identified as a positional candidate gene and showed markedly reduced expression in retina and 
skin from affected animals [148]. Investigation of TRPM1 in humans with complete CSNB identified mutations in TRPM1 [149-151] and its role in ON-bipolar cell signaling was identified.

The LP mutation was identified as a retroviral insertion in intron 1 of equine Trpm 1 that disrupts gene transcription by causing premature polyadenylation [152].

\subsection{Whippet Dog Model of Incomplete CSNB with Retinal Degeneration}

A dog model of cone-rod synaptic dysfunction, which has been described by some authors as a form of incomplete CSNB, has been identified [153]. The affected dogs lack an ERG b-wave and also lack cone OFF-bipolar cell attributable ERG components [154]. Interestingly, the dog model develops a progressive retinal degeneration, which is not reported as a feature of the condition in humans [155].

\section{Structural/Other}

Retinal degenerations can occur due to mutations in genes involved in the structure or maintenance of the retina.

\subsection{ADAM9}

ADAM9 (a disintegrin and metalloprotease domain, family member 9) mutations are associated with cone-rod dystrophies in humans and dogs. A genomic deletion in Adam 9 was identified in Irish Glen of Imaal Terriers, resulting in a premature stop codon and the loss of the full-length protein. Similar to the mouse model, histological sections show that the RPE cells do not invest in the outer segments of the photoreceptors. This mutation effects both the rod and cone photoreceptors, but the cones are more severely affected throughout the course of the disease [156,157]. Further work is needed to understand the role of ADAM9 in the retinal structure and RPE maintenance of photoreceptors.

\subsection{AIPL1}

Mutations in the gene encoding aryl hydrocarbon receptor-interacting protein-like 1 (AIPL1) causes LCA4 accounting for about $3 \%$ to $7 \%$ of autosomal recessive LCA $[132,134,158-160]$. The AIPL1 gene encodes for a protein expressed in the photoreceptor and pineal gland [161]. In photoreceptors, AIPL1 is concentrated in the tip of the inner segment in proximity to the connecting cilia, acting as a co-chaperone involved in the folding, assembly and transport of the retinal cGMP phosphodiesterase (PDE6) heteromeric holoenzyme within photoreceptor outer segments [162-166].

One spontaneous occurring feline large animal model of LCA4 currently exists, the Persian cat [167]. This feline model, similar to human patients with LCA4, presents as an autosomal recessive severe retinal dystrophy. The disease is characterized by a very early photoreceptor loss, progressing to severe retinal degeneration before adulthood. This leads to very early blindness [167]. The feline phenotype is caused by a nonsense mutation at position c.577C $>\mathrm{T}$ producing a stop codon (p.Arg193Ter), leading to the production of a truncated non-functional protein [168]. The precise mechanisms of the severe phenotype in the feline model are yet to be investigated. The feline model represents a valuable large animal model for mechanistic studies underlying AIPL1-LCA in humans.

\subsection{MERTK}

Mutations in MERTK (MER proto-concogene, tyrosine kinase) account for about $1 \%$ of arRP. Mertk was found to be overexpressed (six-fold) in Swedish Vallhund dogs with a retinal dystrophy [169]. After whole genome sequencing of an affected dog, an intact LINE-1 insertion was identified in intron one of Mertk. A LINE-1 retrotransposon is a long interspersed repetitive element that is found in all mammalian genomes [170]. It is unclear how this insertion results in overexpression of the Mertk transcript and subsequent development of retinal disease. More in-depth investigation of this mechanism will aid a better understanding of how retrotransposon insertions can modify gene 
regulation/expression, ultimately leading to disease, in addition to understanding the specific role of overexpression of the MERTK transcript in the context of retinal disease [171].

\subsection{PRCD}

Progressive rod-cone degeneration (Prcd) was a formerly unknown gene that was mapped and sequenced first in dogs with progressive rod-cone degeneration (PRCD) PRA [172]. Dogs with this form of PRA had been studied in detail over many years and many different breeds of dog are affected. The mutation is p.Cys2Tyr, which is in a highly conserved region of the gene. An identical mutation was found in a human RP patient. Additional mutations also located in exon 1 of $P R C D$ have been identified in RP patients [172,173]. Since the discovery of $P r c d$, a mouse knockout model has been generated and experiments have shown Prcd's involvement in photoreceptor disc formation and maintenance [174-176]. Studies in the PRCD dog showed an early ultrastructural change that may have resulted from this purported function. This was the development of vesicular profiles adjacent to outer segments being consistent with abnormality in disc formation, furthermore studies also showed affected dogs had slower photoreceptor disc renewal than normal controls [177].

\section{5. $R D 3$}

Mutations in RD3 result in LCA12 in humans, a severe retinal degeneration in mice and rod-cone dysplasia type 2 ( $r c d 2)$ in Collie dogs [178-180]. RD3 is thought to act as competitor for guanylyl cyclase-activating proteins, preventing premature cyclase activity in inner segments [181].

Collie dogs have a 22 bp insertion in the $R d 3$ gene resulting in altered amino acids and an extended open reading frame [182]. Three splice variants of the gene were identified in the canine retina. In the Rd3-mutant Collie, the rod and cone photoreceptors outer segments do not fully develop and the retina degenerates rapidly. By 6 months, there are no photoreceptor inner or outer segments and the outer nuclear layer contains only one layer of nuclei [183].

\section{Conclusions}

IRDs that lead to visual impairment and blindness show considerable heterogeneity, where even similar disease phenotypes can result from mutations in a wide range of different genes. Closer examination of the broad phenotypes such as RP and LCA show the genetic heterogeneity with altered function of a range of genes leading to photoreceptor loss. Large numbers of different mutations within a single gene exist and can result in a range of phenotypic differences.

The mechanisms by which the gene mutation leads to cell death differs between genes and between mutations within individual genes. Laboratory rodents have been the workhorses for studying disease mechanisms because of the ease with which their genome can be engineered, the short reproductive time and relatively low costs of maintenance. They have allowed identification of disease pathways and allowed the study of how and why degeneration occurs. However, laboratory rodents have very significant shortcomings. Rodents are nocturnal animals with a different pattern of distribution of photoreceptors to humans. The large animal models discussed in this review have retinal photoreceptor distribution that is much closer to that of humans. This is particularly important when considering conditions that have a major effect on the macula. Large animal models have also been of value for the development and testing of translational therapies. They are particularly valuable for this because the larger eye size and proportions of lens and vitreous is much closer to that in humans, allowing for identical surgical approaches for trials of translational therapies. The several, mostly spontaneously occurring, large animal models mentioned here have provided valuable information about disease phenotypes and disease mechanisms. They offer great potential for even more detailed studies to understand how photoreceptor function and survivability is affected by the gene mutations and to study the extensive inner retinal remodeling and glial cell activation that occurs in IRDs. Modeling of IRDs using retinal organoids developed from induced pluripotent stem cells from IRD patients is an exciting field of research. These potentially allow the study of the effect of the exact mutation that is 
present in the patient and in a human cultured tissue. However, they do not yet fully recapitulate the specific environment within the retina of a living animal, so, while showing great promise, they cannot yet replace whole animal studies. Improving our understanding of how and why photoreceptors die may suggest novel therapies to preserve function and slow down vision loss. There remain untapped populations of companion animals (dogs and cats) with spontaneous IRDs, with new potential models being identified with increasing frequency. The advances in gene editing also expand the opportunity to develop additional large animal models with specific mutations that even more accurately model human IRDs.

Supplementary Materials: The following are available online at http://www.mdpi.com/2073-4409/9/4/882/s1, Table S1: List of mutations in large animal models of inherited retinal disease and references.

Author Contributions: All authors contributed to the conception, design and writing of the manuscript. All authors have read and agreed to the published version of the manuscript.

Funding: The NIH (EY027285) and the Donald R. Myers and William E. Dunlap Endowment for Canine Health, to Simon Petersen-Jones, provided support for the work done in this review.

Conflicts of Interest: The authors declare no conflict of interest.

\section{References}

1. Fan, N.; Lai, L. Genetically Modified Pig Models for Human Diseases. J. Genet. Genom. 2013, 40, 67-73. [CrossRef] [PubMed]

2. Petersen-Jones, S.M. Drug and gene therapy of hereditary retinal disease in dog and cat models. Drug Discov. Today Dis. Model. 2013, 10, e215-e223. [CrossRef]

3. Peterson, S.M.; McGill, T.J.; Puthussery, T.; Stoddard, J.; Renner, L.; Lewis, A.D.; Colgin, L.M.; Gayet, J.; Wang, X.; Prongay, K.; et al. Bardet-Biedl Syndrome in rhesus macaques: A nonhuman primate model of retinitis pigmentosa. Exp. Eye Res. 2019, 189, 107825. [CrossRef]

4. Moshiri, A.; Chen, R.; Kim, S.; Harris, R.A.; Li, Y.; Raveendran, M.; Davis, S.; Liang, Q.; Pomerantz, O.; Wang, J.; et al. A nonhuman primate model of inherited retinal disease. J. Clin. Investig. 2019, 129, 863-874. [CrossRef]

5. Luo, X.; Li, M.; Su, B. Application of the genome editing tool CRISPR/Cas9 in non-human primates. Zool. Res. 2016, 37, 214-219.

6. Kang, Y.; Chu, C.; Wang, F.; Niu, Y. CRISPR/Cas9-mediated genome editing in nonhuman primates. Dis. Model. Mech. 2019, 12, dmm039982. [CrossRef] [PubMed]

7. Rahman, N.; Georgiou, M.; Khan, K.N.; Michaelides, M. Macular dystrophies: Clinical and imaging features, molecular genetics and therapeutic options. Br. J. Ophthalmol. 2019, 104, 451-460. [CrossRef]

8. Michaelides, M.; Hunt, D.M.; Moore, A.T. The genetics of inherited macular dystrophies. J. Med. Genet. 2003, 40, 641-650. [CrossRef]

9. Fritsche, L.G.; Igl, W.; Bailey, J.N.C.; Grassmann, F.; Sengupta, S.; Bragg-Gresham, J.L.; Burdon, K.P.; Hebbring, S.J.; Wen, C.; Gorski, M.; et al. A large genome-wide association study of age-related macular degeneration highlights contributions of rare and common variants. Nat. Genet. 2015, 48, 134-143. [CrossRef]

10. Heesterbeek, T.J.; Lorés-Motta, L.; Hoyng, C.B.; Lechanteur, Y.T.E.; Hollander, A.I.D. Risk factors for progression of age-related macular degeneration. Ophthalmic Physiol. Opt. 2020, 40, 140-170. [CrossRef]

11. Nishiguchi, K.; Yokoyama, Y.; Fujii, Y.; Furukawa, T.; Ono, F.; Shimozawa, N.; Togo, M.; Suzuki, M.; Nakazawa, T. Association between drusen and blood test results in a colony of 1174 monkeys. Acta Ophthalmol. 2015, 93, 93. [CrossRef]

12. Pennesi, M.E.; Neuringer, M.; Courtney, R.J. Animal models of age related macular degeneration. Mol. Asp. Med. 2012, 33, 487-509. [CrossRef] [PubMed]

13. Mowat, F.M.; Petersen-Jones, S.M.; Williamson, H.; Williams, D.L.; Luthert, P.J.; Ali, R.R.; Bainbridge, J.W. Topographical characterization of cone photoreceptors and the area centralis of the canine retina. Mol. Vis. 2008, 14, 2518-2527. [PubMed]

14. Beltran, W.A.; Cideciyan, A.V.; Guziewicz, K.E.; Iwabe, S.; Swider, M.; Scott, E.M.; Savina, S.V.; Ruthel, G.; Stefano, F; Zhang, L.; et al. Canine Retina Has a Primate Fovea-Like Bouquet of Cone Photoreceptors Which Is Affected by Inherited Macular Degenerations. PLoS ONE 2014, 9, e90390. [CrossRef] 
15. El-Aziz, M.M.A.; Barragan, I.; O’Driscoll, C.A.; Goodstadt, L.; Prigmore, E.; Borrego, S.; Mena, M.; Pieras, J.I.; El-Ashry, M.F.; Abu Safieh, L.; et al. EYS, encoding an ortholog of Drosophila spacemaker, is mutated in autosomal recessive retinitis pigmentosa. Nat. Genet. 2008, 40, 1285-1287. [CrossRef]

16. Acland, G.M.; Aguirre, G.D.; Ray, J.; Zhang, Q.; Aleman, T.S.; Cideciyan, A.V.; Pearce-Kelling, S.E.; Anand, V.; Zeng, Y.; Maguire, A.M.; et al. Gene therapy restores vision in a canine model of childhood blindness. Nat. Genet. 2001, 28, 92-95. [CrossRef]

17. Athanasiou, D.; Aguila, M.; Bellingham, J.; Li, W.; McCulley, C.; Reeves, P.J.; Cheetham, M.E. The molecular and cellular basis of rhodopsin retinitis pigmentosa reveals potential strategies for therapy. Prog. Retin. Eye Res. 2017, 62, 1-23. [CrossRef]

18. Kijas, J.W.; Cideciyan, A.V.; Aleman, T.S.; Pianta, M.; Pearce-Kelling, S.E.; Miller, B.J.; Jacobson, S.G.; Aguirre, G.D.; Acland, G.M. Naturally occurring rhodopsin mutation in the dog causes retinal dysfunction and degeneration mimicking human dominant retinitis pigmentosa. Proc. Natl. Acad. Sci. USA 2002, 99, 6328-6333. [CrossRef]

19. Iwabe, S.; Ying, G.-S.; Aguirre, G.D.; Beltran, W.A. Assessment of visual function and retinal structure following acute light exposure in the light sensitive T4R rhodopsin mutant dog. Exp. Eye Res. 2016, 146, 341-353. [CrossRef]

20. Born, L.I.V.D.; Van Schooneveld, M.J.; De Jong, L.A.M.S.; Riemslag, F.C.C.; DeJong, P.T.V.M.; Gal, A.; Bleeker-Wagemakers, E.M. Thr4Lys rhodopsin mutation is associated with autosomal dominant retinitis pigmentosa of the cone-rod type in a small Dutch family. Ophthalmic Genet. 1994, 15, 51-60. [CrossRef]

21. Zhu, L.; Jang, G.-F.; Jastrzebska, B.; Filipek, S.; Pearce-Kelling, S.E.; Aguirre, G.D.; Stenkamp, R.E.; Acland, G.M.; Palczewski, K. A naturally occurring mutation of the opsin gene (T4R) in dogs affects glycosylation and stability of the G protein-coupled receptor. J. Boil. Chem. 2004, 279, 53828-53839. [CrossRef] [PubMed]

22. Heckenlively, J.R.; Rodriguez, J.A.; Daiger, S.P. Autosomal Dominant Sectoral Retinitis Pigmentosa. Arch. Ophthalmol. 1991, 109, 84. [CrossRef] [PubMed]

23. Orlans, H.O.; MacLaren, R.E. Comment on: 'Sector retinitis pigmentosa caused by mutations of the RHO gene'. Eye 2019, 1-2. [CrossRef] [PubMed]

24. Ross, J.W.; De Castro, J.P.F.; Zhao, J.; Samuel, M.; Walters, E.; Rios, C.; Bray-Ward, P.; Jones, B.W.; Marc, R.E.; Wang, W.; et al. Generation of an Inbred Miniature Pig Model of Retinitis Pigmentosa. Investig. Opthalmol. Vis. Sci. 2012, 53, 501-507. [CrossRef] [PubMed]

25. Petters, R.M.; Alexander, C.A.; Wells, K.D.; Collins, E.B.; Sommer, J.; Blanton, M.R.; Rojas, G.; Hao, Y.; Flowers, W.L.; Banin, E.; et al. Genetically engineered large animal model for studying cone photoreceptor survival and degeneration in retinitis pigmentosa. Nat. Biotechnol. 1997, 15, 965-970. [CrossRef]

26. Kraft, T.; Allen, D.; Petters, R.M.; Hao, Y.; Peng, Y.-W.; Wong, F. Altered light responses of single rod photoreceptors in transgenic pigs expressing P347L or P347S rhodopsin. Mol. Vis. 2005, 11, 1246-1256.

27. Peng, Y.-W.; Hao, Y.; Petters, R.M.; Wong, F. Ectopic synaptogenesis in the mammalian retina caused by rod photoreceptor-specific mutations. Nat. Neurosci. 2000, 3, 1121-1127. [CrossRef]

28. Banin, E.; Cideciyan, A.V.; Aleman, T.S.; Petters, R.M.; Wong, F.; Milam, A.H.; Jacobson, S.G. Retinal Rod Photoreceptor-Specific Gene Mutation Perturbs Cone Pathway Development. Neuron 1999, 23, 549-557. [CrossRef]

29. Shen, J.; Yang, X.; Dong, A.; Petters, R.M.; Peng, Y.-W.; Wong, F.; Campochiaro, P.A. Oxidative damage is a potential cause of cone cell death in retinitis pigmentosa. J. Cell. Physiol. 2005, 203, 457-464. [CrossRef]

30. Sommer, J.R.; Wong, F.; Petters, R.M. Phenotypic stability of Pro347Leu rhodopsin transgenic pigs as indicated by photoreceptor cell degeneration. Transgenic Res. 2011, 20, 1391-1395. [CrossRef]

31. Wang, W.; Lee, S.J.; Scott, P.A.; Lu, X.; Emery, D.; Liu, Y.; Ezashi, T.; Roberts, M.R.; Ross, J.W.; Kaplan, H.J.; et al. Two-Step Reactivation of Dormant Cones in Retinitis Pigmentosa. Cell Rep. 2016, 15, 372-385. [CrossRef] [PubMed]

32. Daiger, S.P.; Bowne, S.J.; Sullivan, L.S. Perspective on Genes and Mutations Causing Retinitis Pigmentosa. Arch. Ophthalmol. 2007, 125, 151-158. [CrossRef] [PubMed]

33. Baehr, W.; Devlin, M.J.; Applebury, M.L. Isolation and characterization of cGMP phosphodiesterase from bovine rod outer segments. J. Boil. Chem. 1979, 254, 11669-11677.

34. Petersen-Jones, S.M.; Entz, D.D.; Sargan, D.R. cGMP phosphodiesterase- $\alpha$ mutation causes progressive retinal atrophy in the Cardigan Welsh corgi dog. Investig. Ophthalmol. Vis. Sci. 1999, 40, 1637-1644. 
35. Tuntivanich, N.; Pittler, S.J.; Fischer, A.J.; Omar, G.; Kiupel, M.; Weber, A.; Yao, S.; Steibel, J.P.; Khan, N.W.; Petersen-Jones, S.M. Characterization of a canine model of autosomal recessive retinitis pigmentosa due to a PDE6A mutation. Investig. Opthalmol. Vis. Sci. 2008, 50, 801-813. [CrossRef] [PubMed]

36. Dryja, T.P.; Finn, J.T.; Peng, Y.W.; McGee, T.L.; Berson, E.L.; Yau, K.W. Mutations in the gene encoding the alpha subunit of the rod cGMP-gated channel in autosomal recessive retinitis pigmentosa. Proc. Natl. Acad. Sci. USA 1995, 92, 10177-10181. [CrossRef]

37. Huang, S.H.; Pittler, S.J.; Huang, X.; Oliveira, L.; Berson, E.L.; Dryja, T.P. Autosomal recessive retinitis pigmentosa caused by mutations in the $\alpha$ subunit of rod cGMP phosphodiesterase. Nat. Genet. 1995, 11, 468-471. [CrossRef]

38. Suber, M.L.; Pittler, S.J.; Qin, N.; Wright, G.C.; Holcombe, V.; Lee, R.H.; Craft, C.M.; Lolley, R.N.; Baehr, W.; Hurwitz, R.L. Irish setter dogs affected with rod/cone dysplasia contain a nonsense mutation in the rod cGMP phosphodiesterase beta-subunit gene. Proc. Natl. Acad. Sci. USA 1993, 90, 3968-3972. [CrossRef]

39. Hartong, D.T.; Berson, E.L.; Dryja, T.P. Retinitis pigmentosa. Lancet 2006, 368, 1795-1809. [CrossRef]

40. McLaughlin, M.E.; Ehrhart, T.L.; Berson, E.L.; Dryja, T.P. Mutation spectrum of the gene encoding the beta subunit of rod phosphodiesterase among patients with autosomal recessive retinitis pigmentosa. Proc. Natl. Acad. Sci. USA 1995, 92, 3249-3253. [CrossRef]

41. Occelli, L.M.; Schön, C.; Seeliger, M.W.; Biel, M.; Michalakis, S.; Petersen-Jones, S.M.; The RD-Cure Consortium. Gene Supplementation Rescues Rod Function and Preserves Photoreceptor and Retinal Morphology in Dogs, Leading the Way Toward Treating Human PDE6A-Retinitis Pigmentosa. Hum. Gene Ther. 2017, 28, 1189-1201. [CrossRef] [PubMed]

42. Arango-Gonzalez, B.; Trifunović, D.; Sahaboglu, A.; Kranz, K.; Michalakis, S.; Farinelli, P.; Koch, S.; Koch, F.; Cottet, S.; Janssen-Bienhold, U.; et al. Identification of a Common Non-Apoptotic Cell Death Mechanism in Hereditary Retinal Degeneration. PLoS ONE 2014, 9, e112142. [CrossRef] [PubMed]

43. Wensel, T.G.; Zhang, Z.; Anastassov, I.; Gilliam, J.C.; He, F.; Schmid, M.F.; Robichaux, M.A. Structural and molecular bases of rod photoreceptor morphogenesis and disease. Prog. Retin. Eye Res. 2016, 55, 32-51. [CrossRef] [PubMed]

44. Mowat, F.M.; Occelli, L.M.; Bartoe, J.T.; Gervais, K.J.; Bruewer, A.R.; Querubin, J.; Dinculescu, A.; Boye, S.L.; Hauswirth, W.; Petersen-Jones, S.M. Gene Therapy in a Large Animal Model of PDE6A-Retinitis Pigmentosa. Front. Mol. Neurosci. 2017, 11, 342. [CrossRef]

45. Clements, P.J.M.; Gregory, C.Y.; Petersen-Jones, S.M.; Sargan, D.R.; Bhattacharya, S.S. Confirmation of the rod cGMP phophodiesterase á-subunit (PDEá) nonsense mutation in affected rcd-1 Irish setters in the UK and development of a diagnostic test. Curr. Eye Res. 1993, 12, 861-866. [CrossRef]

46. Farber, D.B.; Danciger, J.S.; Aguirre, G. The beta subunit of cyclic GMP phosphodiesterase mRNA is deficient in canine rod-cone dysplasia 1. Neuron 1992, 9, 349-356. [CrossRef]

47. Aguirre, G.; Farber, D.; Lolley, R.; O’Brien, P.; Alligood, J.; Fletcher, R.T.; Chader, G. Retinal degenerations in the dog III abnormal cyclic nucleotide metabolism in rod-cone dysplasia. Exp. Eye Res. 1982, 35, 625-642. [CrossRef]

48. Aguirre, G.D.; Rubin, L.F. Rod-cone dysplasia (progressive retinal atrophy) in Irish setters. J. Am. Veter Med. Assoc. 1975, 166, 157-164.

49. Aquirre, G.; Farber, D.; Lolley, R.; Fletcher, R.; Chader, G. Rod-cone dysplasia in Irish setters: A defect in cyclic GMP metabolism in visual cells. Science 1978, 201, 1133-1134. [CrossRef]

50. Pichard, V.; Provost, N.; Mendes-Madeira, A.; Libeau, L.; Hulin, P.; Tshilenge, K.-T.; Biget, M.; Ameline, B.; Deschamps, J.-Y.; Weber, M.; et al. AAV-mediated Gene Therapy Halts Retinal Degeneration in PDE6ß-deficient Dogs. Mol. Ther. 2016, 24, 867-876. [CrossRef]

51. Dekomien, G.; Runte, M.; Gödde, R.; Epplen, J.T. Generalized progressive retinal atrophy of Sloughi dogs is due to an 8-bp insertion in exon 21 of the PDE6B gene. Cytogenet. Cell Genet. 2000, 90, 261-267. [CrossRef] [PubMed]

52. Goldstein, O.; Mezey, J.G.; Schweitzer, P.A.; Boyko, A.R.; Gao, C.; Bustamante, C.D.; Jordan, J.A.; Aguirre, G.D.; Acland, G.M. IQCB1 and PDE6B Mutations Cause Similar Early Onset Retinal Degenerations in Two Closely Related Terrier Dog Breeds. Investig. Opthalmol. Vis. Sci. 2013, 54, 7005-7019. [CrossRef] [PubMed]

53. Quazi, F.; Lenevich, S.; Molday, R.S. ABCA4 is an N-retinylidene-phosphatidylethanolamine and phosphatidylethanolamine importer. Nat. Commun. 2012, 3, 925. [CrossRef] [PubMed] 
54. Mäkeläinen, S.; Gòdia, M.; Hellsand, M.; Viluma, A.; Hahn, D.; Makdoumi, K.; Zeiss, C.J.; Mellersh, C.; Ricketts, S.L.; Narfström, K.; et al. An ABCA4 loss-of-function mutation causes a canine form of Stargardt disease. PLoS Genet. 2019, 15, e1007873. [CrossRef] [PubMed]

55. Maeda, A.; Maeda, T.; Golczak, M.; Palczewski, K. Retinopathy in mice induced by disrupted all-trans-retinal clearance. J. Boil. Chem. 2008, 283, 26684-26693. [CrossRef]

56. Tsang, S.H.; Sharma, T. Stargardt Disease. In Atlas of Inherited Retinal Diseases; Tsang, S.H., Sharma, T., Eds.; Springer International Publishing: Cham, Switzerland, 2018; pp. 139-151. [CrossRef]

57. Le Meur, G.; Stieger, K.; Smith, A.J.; Weber, M.; Deschamps, J.Y.; Nivard, D.; Mendes-Madeira, A.; Provost, N.; Péréon, Y.; Cherel, Y.; et al. Restoration of vision in RPE65-deficient Briard dogs using an AAV serotype 4 vector that specifically targets the retinal pigmented epithelium. Gene Ther. 2006, 14, 292-303. [CrossRef]

58. Narfström, K.; Katz, M.L.; Bragadottir, R.; Seeliger, M.; Boulanger, A.; Redmond, T.M.; Caro, L.; Lai, C.-M.; Rakoczy, P.E. Functional and structural recovery of the retina after gene therapy in the RPE65 null mutation dog. Investig. Opthalmol. Vis. Sci. 2003, 44, 1663-1672. [CrossRef]

59. Annear, M.J.; Bartoe, J.T.; Barker, S.E.; Smith, A.J.; Curran, P.G.; Bainbridge, J.W.; Ali, R.R.; Petersen-Jones, S.M. Gene therapy in the second eye of RPE65-deficient dogs improves retinal function. Gene Ther. 2010, 18, 53-61. [CrossRef]

60. Annear, M.J.; Mowat, F.M.; Bartoe, J.T.; Querubin, J.; Azam, S.A.; Basche, M.; Curran, P.G.; Smith, A.; Bainbridge, J.W.; Ali, R.R.; et al. Successful Gene Therapy in Older Rpe65-Deficient Dogs Following Subretinal Injection of an Adeno-Associated Vector Expressing RPE65. Hum. Gene Ther. 2013, 24, 883-893. [CrossRef]

61. Mowat, F.M.; Breuwer, A.R.; Bartoe, J.T.; Annear, M.J.; Zhang, Z.; Smith, A.J.; Bainbridge, J.W.; Petersen-Jones, S.M.; Ali, R.R. RPE65 gene therapy slows cone loss in Rpe65-deficient dogs. Gene Ther. 2012, 20, 545-555. [CrossRef]

62. Mowat, F.M.; Gervais, K.J.; Occelli, L.M.; Annear, M.J.; Querubin, J.; Bainbridge, J.W.; Smith, A.J.; Ali, R.R.; Petersen-Jones, S.M. Early-Onset Progressive Degeneration of the Area Centralis in RPE65-Deficient Dogs. Investig. Opthalmol. Vis. Sci. 2017, 58, 3268. [CrossRef] [PubMed]

63. Bainbridge, J.W.; Mehat, M.S.; Sundaram, V.; Robbie, S.J.; Barker, S.E.; Ripamonti, C.; Georgiadis, A.; Mowat, F.M.; Beattie, S.G.; Gardner, P.; et al. Long-Term Effect of Gene Therapy on Leber's Congenital Amaurosis. N. Engl. J. Med. 2015, 372, 1887-1897. [CrossRef] [PubMed]

64. Petersen-Jones, S.M.; Occelli, L.; Winkler, P.; Minella, A.; Sun, K.; Lyons, L.; Daruwalla, A.; Kiser, P.; Palczewski, K. New large animal model for RDH5-associated retinopathies. Investig. Ophthalmol. Vis. Sci. 2019, 60, 458.

65. Gonzalez-Fernandez, F.; Kurz, D.; Bao, Y.; Newman, S.; Conway, B.P.; Young, J.E.; Han, D.P.; Khani, S.C. 11-cis retinol dehydrogenase mutations as a major cause of the congenital night-blindness disorder known as fundus albipunctatus. Mol. Vis. 1999, 5, 41. [PubMed]

66. Hotta, K.; Nakamura, M.; Kondo, M.; Ito, S.; Terasaki, H.; Miyake, Y.; Hida, T. Macular dystrophy in a Japanese family with fundus albipunctatus. Am. J. Ophthalmol. 2003, 135, 917-919. [CrossRef]

67. Nakamura, M.; Miyake, Y. Macular dystrophy in a 9-year-old boy with fundus albipunctatus. Am. J. Ophthalmol. 2002, 133, 278-280. [CrossRef]

68. Nakamura, M.; Skalet, J.; Miyake, Y. RDH5 gene mutations and electroretinogram in fundus albipunctatus with or without macular dystrophy: RDH5 mutations and ERG in fundus albipunctatus. Doc. Ophthalmol. 2003, 107, 3-11. [CrossRef]

69. Yamamoto, H.; Yakushijin, K.; Kusuhara, S.; Escaño, M.F.T.; Nagai, A.; Negi, A. A novel RDH5 gene mutation in a patient with fundus albipunctatus presenting with macular atrophy and fading white dots. Am. J. Ophthalmol. 2003, 136, 572-574. [CrossRef]

70. Kuehlewein, L.; Nasser, F.; Gloeckle, N.; Kohl, S.; Zrenner, E. Fundus albipunctatus associated with cone dysfunction. Retin. Cases Brief Rep. 2017, 11, S73-S76. [CrossRef]

71. Kim, T.S.; Maeda, A.; Maeda, T.; Heinlein, C.; Kedishvili, N.; Palczewski, K.; Nelson, P.S. Delayed dark adaptation in 11-cis-retinol dehydrogenase-deficient mice: A role of RDH11 in visual processes in vivo. J. Boil. Chem. 2005, 280, 8694-8704. [CrossRef]

72. Kaupp, U.B.; Seifert, R. Cyclic Nucleotide-Gated Ion Channels. Physiol. Rev. 2002, 82, 769-824. [CrossRef] [PubMed] 
73. Zheng, J.; Trudeau, M.C.; Zagotta, W.N. Rod cyclic nucleotide-gated channels have a stoichiometry of three CNGA1 subunits and one CNGB1 subunit. Neuron 2002, 36, 891-896. [CrossRef]

74. Zhong, H.; Molday, L.L.; Molday, R.S.; Yau, K.-W. The heteromeric cyclic nucleotide-gated channel adopts a 3A:1B stoichiometry. Nature 2002, 420, 193-198. [CrossRef] [PubMed]

75. Johnson, A.A.; Guziewicz, K.E.; Lee, C.J.; Kalathur, R.C.; Pulido, J.S.; Marmorstein, L.Y.; Marmorstein, A.D. Bestrophin 1 and retinal disease. Prog. Retin. Eye Res. 2017, 58, 45-69. [CrossRef] [PubMed]

76. Wiik, A.C.; Ropstad, E.O.; Ekesten, B.; Karlstam, L.; Wade, C.; Lingaas, F. Progressive retinal atrophy in Shetland sheepdog is associated with a mutation in theCNGA1gene. Anim. Genet. 2015, 46, 515-521. [CrossRef] [PubMed]

77. Winkler, P.A.; Ekenstedt, K.J.; Occelli, L.M.; Frattaroli, A.V.; Bartoe, J.T.; Venta, P.J.; Petersen-Jones, S.M. A Large Animal Model for CNGB1 Autosomal Recessive Retinitis Pigmentosa. PLoS ONE 2013, 8, 72229. [CrossRef]

78. Petersen-Jones, S.M.; Occelli, L.M.; Winkler, P.A.; Lee, W.; Sparrow, J.R.; Tsukikawa, M.; Boye, S.L.; Chiodo, V.; Capasso, J.E.; Becirovic, E.; et al. Patients and animal models of CNG $\beta 1$-deficient retinitis pigmentosa support gene augmentation approach. J. Clin. Investig. 2017, 128, 190-206. [CrossRef]

79. Hüttl, S.; Michalakis, S.; Seeliger, M.; Luo, N.-G.; Acar, N.; Geiger, H.; Hudl, K.; Mader, R.; Haverkamp, S.; Moser, M.; et al. Impaired channel targeting and retinal degeneration in mice lacking the cyclic nucleotide-gated channel subunit CNGB1. J. Neurosci. 2005, 25, 130-138. [CrossRef]

80. Hull, S.; Attanasio, M.; Arno, G.; Carss, K.; Robson, A.; Thompson, D.; Plagnol, V.; Michaelides, M.; Holder, G.E.; Henderson, R.H.; et al. Clinical Characterization of CNGB1-Related Autosomal Recessive Retinitis Pigmentosa. JAMA Ophthalmol. 2017, 135, 137-144. [CrossRef]

81. Wissinger, B.; Gamer, D.; Jägle, H.; Giorda, R.; Marx, T.; Mayer, S.; Tippmann, S.; Broghammer, M.; Jurklies, B.; Rosenberg, T.; et al. CNGA3 Mutations in Hereditary Cone Photoreceptor Disorders. Am. J. Hum. Genet. 2001, 69, 722-737. [CrossRef]

82. Tanaka, N.; Dutrow, E.; Miyadera, K.; Delemotte, L.; MacDermaid, C.; Reinstein, S.L.; Crumley, W.R.; Dixon, C.J.; Casal, M.L.; Klein, M.L.; et al. Canine CNGA3 Gene Mutations Provide Novel Insights into Human Achromatopsia-Associated Channelopathies and Treatment. PLoS ONE 2015, 10, e0138943. [CrossRef] [PubMed]

83. Reicher, S.; Seroussi, E.; Gootwine, E. A mutation in gene CNGA3 is associated with day blindness in sheep. Genomics 2010, 95, 101-104. [CrossRef] [PubMed]

84. Gootwine, E.; Abu-Siam, M.; Obolensky, A.; Rosov, A.; Honig, H.; Nitzan, T.; Shirak, A.; Ezra-Elia, R.; Yamin, E.; Banin, E.; et al. Gene Augmentation Therapy for a Missense Substitution in the cGMP-Binding Domain of Ovine CNGA3 Gene Restores Vision in Day-Blind Sheep. Investig. Opthalmol. Vis. Sci. 2017, 58, 1577-1584. [CrossRef] [PubMed]

85. Gootwine, E.; Ofri, R.; Banin, E.; Obolensky, A.; Averbukh, E.; Ezra-Elia, R.; Ross, M.; Honig, H.; Rosov, A.; Yamin, E.; et al. Safety and Efficacy Evaluation of rAAV2tYF-PR1.7-hCNGA3 Vector Delivered by Subretinal Injection in CNGA3 Mutant Achromatopsia Sheep. Hum. Gene Ther. Clin. Dev. 2017, 28, 96-107. [CrossRef] [PubMed]

86. Sidjanin, D.J.; Lowe, J.K.; McElwee, J.; Milne, B.S.; Phippen, T.M.; Sargan, D.R.; Aguirre, G.D.; Acland, G.M.; Ostrander, E.A. Canine CNGB3 mutations establish cone degeneration as orthologous to the human achromatopsia locus ACHM3. Hum. Mol. Genet. 2002, 11, 1823-1833. [CrossRef]

87. Yeh, C.Y.; Goldstein, O.; Kukekova, A.; Holley, D.; Knollinger, A.M.; Huson, H.J.; Pearce-Kelling, S.E.; Acland, G.M.; Komáromy, A.M. Genomic deletion of CNGB3 is identical by descent in multiple canine breeds and causes achromatopsia. BMC Genet. 2013, 14, 27. [CrossRef]

88. Kohl, S.; Varsányi, B.; Antunes, G.A.; Baumann, B.; Hoyng, C.B.; Jägle, H.; Rosenberg, T.; Kellner, U.; Lorenz, B.; Salati, R.; et al. CNGB3 mutations account for $50 \%$ of all cases with autosomal recessive achromatopsia. Eur. J. Hum. Genet. 2004, 13, 302-308. [CrossRef]

89. Tanaka, N.; Delemotte, L.; Klein, M.L.; Komáromy, A.M.; Tanaka, J.C. A Cyclic Nucleotide-Gated Channel Mutation Associated with Canine Daylight Blindness Provides Insight into a Role for the S2 Segment Tri-Asp motif in Channel Biogenesis. PLoS ONE 2014, 9, e88768. [CrossRef]

90. Ye, G.-J.; Komáromy, A.M.; Zeiss, C.; Calcedo, R.; Harman, C.D.; Koehl, K.L.; Stewart, G.A.; Iwabe, S.; Chiodo, V.A.; Hauswirth, W.; et al. Safety and Efficacy of AAV5 Vectors Expressing Human or Canine CNGB3 in CNGB3-Mutant Dogs. Hum. Gene Ther. Clin. Dev. 2017, 28, 197-207. [CrossRef] 
91. Guziewicz, K.E.; Zangerl, B.; Lindauer, S.J.; Mullins, R.F.; Sandmeyer, L.S.; Grahn, B.H.; Stone, E.M.; Acland, G.M.; Aguirre, G.D. Bestrophin gene mutations cause canine multifocal retinopathy: A novel animal model for best disease. Investig. Opthalmol. Vis. Sci. 2007, 48, 1959-1967. [CrossRef]

92. Zangerl, B.; Wickström, K.; Slavik, J.; Lindauer, S.J.; Ahonen, S.; Schelling, C.; Lohi, H.; Guziewicz, K.E.; Aguirre, G.D. Assessment of canine BEST1 variations identifies new mutations and establishes an independent bestrophinopathy model (cmr3). Mol. Vis. 2010, 16, 2791-2804. [PubMed]

93. Guziewicz, K.E.; Cideciyan, A.V.; Beltran, W.A.; Komaromy, A.M.; Dufour, V.L.; Swider, M.; Iwabe, S.; Sumaroka, A.; Kendrick, B.T.; Ruthel, G.; et al. BEST1 gene therapy corrects a diffuse retina-wide microdetachment modulated by light exposure. Proc. Natl. Acad. Sci. USA 2018, 115, E2839-E2848. [CrossRef] [PubMed]

94. Guziewicz, K.E.; McTish, E.; Dufour, V.L.; Zorych, K.; Dhingra, A.; Boesze-Battaglia, K.; Aguirre, G.D. Underdeveloped RPE Apical Domain Underlies Lesion Formation in Canine Bestrophinopathies. Single Mol. Single Cell Seq. 2018, 1074, 309-315.

95. Chew, T.; Haase, B.; Bathgate, R.; Willet, C.; Kaukonen, M.K.; Mascord, L.J.; Lohi, H.; Wade, C. A Coding Variant in the Gene Bardet-Biedl Syndrome 4 (BBS4) Is Associated with a Novel Form of Canine Progressive Retinal Atrophy. G3 Genes Genomes Genet. 2017, 7, 2327-2335. [CrossRef] [PubMed]

96. Narfström, K. Progressive retinal atrophy in the Abyssinian cat. Clinical characteristics. Investig. Ophthalmol. Vis. Sci. 1985, 26, 193-200.

97. Minella, A.L.; Occelli, L.M.; Narfström, K.; Petersen-Jones, S.M. Central retinal preservation in rdAc cats. Veter Ophthalmol. 2017, 21, 224-232. [CrossRef]

98. Coppieters, F.; Lefever, S.; Leroy, B.P.; De Baere, E. CEP290, a gene with many faces: Mutation overview and presentation of CEP290base. Hum. Mutat. 2010, 31, 1097-1108. [CrossRef]

99. Menotti-Raymond, M.; David, V.A.; Schäffer, A.A.; Stephens, R.; Wells, D.; Kumar-Singh, R.; O’Brien, S.; Narfström, K. Mutation in CEP290 Discovered for Cat Model of Human Retinal Degeneration. J. Hered. 2007, 98, 211-220. [CrossRef]

100. Wiik, A.C.; Wade, C.; Biagi, T.; Ropstad, E.-O.; Bjerkås, E.; Lindblad-Toh, K.; Lingaas, F. A deletion in nephronophthisis 4 (NPHP4) is associated with recessive cone-rod dystrophy in standard wire-haired dachshund. Genome Res. 2008, 18, 1415-1421. [CrossRef]

101. Ropstad, E.O.; Narfström, K.; Lingaas, F.; Wiik, C.; Bruun, A.; Bjerkas, E. Functional and Structural Changes in the Retina of Wire-Haired Dachshunds with Early-Onset Cone-Rod Dystrophy. Investig. Opthalmol. Vis. Sci. 2008, 49, 1106-1115. [CrossRef]

102. Ropstad, E.O.; Bjerkås, E.; Narfström, K. Electroretinographic findings in the Standard Wire Haired Dachshund with inherited early onset cone-rod dystrophy. Doc. Ophthalmol. 2006, 114, 27-36. [CrossRef] [PubMed]

103. Ropstad, E.O.; Bjerkås, E.; Narfström, K. Clinical findings in early onset cone-rod dystrophy in the Standard Wire-haired Dachshund. Veter Ophthalmol. 2007, 10, 69-75. [CrossRef] [PubMed]

104. Ronquillo, C.; Bernstein, P.S.; Baehr, W. Senior-Løken syndrome: A syndromic form of retinal dystrophy associated with nephronophthisis. Vis. Res. 2012, 75, 88-97. [CrossRef] [PubMed]

105. Won, J.; De Evsikova, C.M.; Smith, R.S.; Hicks, W.L.; Edwards, M.M.; Longo-Guess, C.; Li, T.; Naggert, J.K.; Nishina, P.M. NPHP4 is necessary for normal photoreceptor ribbon synapse maintenance and outer segment formation, and for sperm development. Hum. Mol. Genet. 2010, 20, 482-496. [CrossRef]

106. Downs, L.M.; Scott, E.M.; Cideciyan, A.V.; Iwabe, S.; Dufour, V.L.; Gardiner, K.L.; Genini, S.; Marinho, L.F.; Sumaroka, A.; Kosyk, M.S.; et al. Overlap of abnormal photoreceptor development and progressive degeneration in Leber congenital amaurosis caused by NPHP5 mutation. Hum. Mol. Genet. 2016, 25, 4211-4226. [CrossRef]

107. Aguirre, G.D.; Cideciyan, A.V.; Boye, S.L.; Iwabe, S.; Dufour, V.; Swider, M.; Roszak, K.; Hauswirth, W.W.; Jacobson, S.G.; Beltran, W.A. Long-term preservation of photoreceptor function and structure following early-stage treatment by AAV-mediated gene augmentation in canine model of NPHP5 Leber congenital amaurosis. Investig. Ophthalmol. Vis. Sci. 2018, 59, 6006.

108. Khanna, H. More Than Meets the Eye: Current Understanding of RPGR Function. In Advances in Experimental Medicine and Biology; Springer: Cham, Switzerland, 2018; pp. 521-538. 
109. Vervoort, R.; Lennon, A.; Bird, A.C.; Tulloch, B.; Axton, R.; Miano, M.G.; Meindl, A.; Meitinger, T.; Ciccodicola, A.; Wright, A.F. Mutational hot spot within a new RPGR exon in X-linked retinitis pigmentosa. Nat. Genet. 2000, 25, 462-466. [CrossRef]

110. Kropatsch, R.; Akkad, D.A.; Frank, M.; Rosenhagen, C.; Altmüller, J.; Nürnberg, P.; Epplen, J.T.; Dekomien, G. A large deletion in RPGR causes XLPRA in Weimaraner dogs. Canine Genet. Epidemiol. 2016, 3, 7. [CrossRef]

111. Zhang, Q.; Acland, G.M.; Wu, W.X.; Johnson, J.; Pearce-Kelling, S.; Tulloch, B.; Vervoort, R.; Wright, A.F.; Aguirre, G.D. Different RPGR exon ORF15 mutations in Canids provide insights into photoreceptor cell degeneration. Hum. Mol. Genet. 2002, 11, 993-1003. [CrossRef]

112. Zeiss, C.J.; Acland, G.M.; Aguirre, G.D. Retinal pathology of canine X-linked progressive retinal atrophy, the locus homologue of RP3. Investig. Ophthalmol. Vis. Sci. 1999, 40, 3292-3304.

113. Beltran, W.A.; Hammond, P.; Acland, G.M.; Aguirre, G.D. A Frameshift Mutation in RPGR Exon ORF15 Causes Photoreceptor Degeneration and Inner Retina Remodeling in a Model of X-Linked Retinitis Pigmentosa. Investig. Opthalmol. Vis. Sci. 2006, 47, 1669-1681. [CrossRef] [PubMed]

114. Beltran, W.A.; Acland, G.M.; Aguirre, G.D. Age-dependent disease expression determines remodeling of the retinal mosaic in carriers of RPGR exon ORF15 mutations. Investig. Opthalmol. Vis. Sci. 2009, 50, 3985-3995. [CrossRef] [PubMed]

115. Mellersh, C.; Boursnell, M.; Pettitt, L.; Ryder, E.; Holmes, N.; Grafham, D.; Forman, O.; Sampson, J.; Barnett, K.; Blanton, S.; et al. Canine RPGRIP1 mutation establishes cone-rod dystrophy in miniature longhaired dachshunds as a homologue of human Leber congenital amaurosis. Genomics 2006, 88, $293-301$. [CrossRef] [PubMed]

116. Lhériteau, E.; Petit, L.; Weber, M.; Le Meur, G.; Deschamps, J.-Y.; Libeau, L.; Mendes-Madeira, A.; Guihal, C.; François, A.; Guyon, R.; et al. Successful Gene Therapy in the RPGRIP1-deficient Dog: A Large Model of Cone-Rod Dystrophy. Mol. Ther. 2013, 22, 265-277. [CrossRef] [PubMed]

117. Kuznetsova, T.; Iwabe, S.; Boesze-Battaglia, K.; Pearce-Kelling, S.; Chang-Min, Y.; McDaid, K.; Miyadera, K.; Komaromy, A.; Aguirre, G.D. Exclusion of RPGRIP1 ins44 from Primary Causal Association with Early-Onset Cone-Rod Dystrophy in Dogs. Investig. Opthalmol. Vis. Sci. 2012, 53, 5486-5501. [CrossRef]

118. Forman, O.P.; Hitti, R.J.; Boursnell, M.; Miyadera, K.; Sargan, D.R.; Mellersh, C. Canine genome assembly correction facilitates identification of a MAP9 deletion as a potential age of onset modifier for RPGRIP1-associated canine retinal degeneration. Mamm. Genome 2016, 27, 237-245. [CrossRef]

119. Miyadera, K.; Kato, K.; Boursnell, M.; Mellersh, C.; Sargan, D.R. Genome-wide association study in RPGRIP1 $^{-/-}$dogs identifies a modifier locus that determines the onset of retinal degeneration. Mamm. Genome 2011, 23, 212-223. [CrossRef]

120. Miyadera, K.; Murgiano, L.; Spector, C.; Marinho, F.P.; Dufour, V.; Das, R.G.; Brooks, M.; Swaroop, A.; Aguirre, G.D. Isolated population helps tease out a third locus underlying a multigenic form of canine RPGRIP1 cone-rod dystrophy. Investig. Ophthalmol. Vis. Sci. 2018, 59, 1438.

121. Chau, K.-Y.; Chen, S.; Zack, D.J.; Ono, S.J. Functional Domains of the Cone-Rod Homeobox (CRX) Transcription Factor. J. Boil. Chem. 2000, 275, 37264-37270. [CrossRef]

122. Morrow, E.M.; Furukawa, T.; Raviola, E.; Cepko, C.L. Synaptogenesis and outer segment formation are perturbed in the neural retina of Crx mutant mice. BMC Neurosci. 2005, 6, 5. [CrossRef]

123. Chen, S.; Wang, Q.-L.; Nie, Z.; Sun, H.; Lennon, G.; Copeland, N.; Gilbert, D.J.; Jenkins, N.A.; Zack, D.J. Crx, a novel Otx-like paired-homeodomain protein, binds to and transactivates photoreceptor cell-specific genes. Neuron 1997, 19, 1017-1030. [CrossRef]

124. Furukawa, T.; Morrow, E.M.; Cepko, C.L. Crx, a novel otx-like homeobox gene, shows photoreceptor-specific expression and regulates photoreceptor differentiation. Cell 1997, 91, 531-541. [CrossRef]

125. Hennig, A.K.; Peng, G.-H.; Chen, S. Regulation of photoreceptor gene expression by Crx-associated transcription factor network. Brain Res. 2007, 1192, 114-133. [CrossRef] [PubMed]

126. Peng, G.-H.; Chen, S. Crx activates opsin transcription by recruiting HAT-containing co-activators and promoting histone acetylation. Hum. Mol. Genet. 2007, 16, 2433-2452. [CrossRef] [PubMed]

127. Menotti-Raymond, M.; Deckman, K.H.; David, V.; Myrkalo, J.; O’Brien, S.J.; Narfström, K. Mutation discovered in a feline model of human congenital retinal blinding disease. Investig. Opthalmol. Vis. Sci. 2010, 51, 2852-2859. [CrossRef] [PubMed] 
128. Occelli, L.M.; Tran, N.M.; Narfström, K.; Chen, S.; Petersen-Jones, S.M. CrxRdy Cat: A Large Animal Model for CRX-Associated Leber Congenital Amaurosis. Investig. Opthalmol. Vis. Sci. 2016, 57, 3780-3792. [CrossRef]

129. Sohocki, M.M.; Sullivan, L.S.; Mintz-Hittner, H.A.; Birch, D.G.; Heckenlively, J.R.; Freund, C.L.; McInnes, R.R.; Daiger, S.P. A range of clinical phenotypes associated with mutations in CRX, a photoreceptor transcription-factor gene. Am. J. Hum. Genet. 1998, 63, 1307-1315. [CrossRef]

130. Hull, S.; Arno, G.; Plagnol, V.; Chamney, S.; Russell-Eggitt, I.; Thompson, D.; Ramsden, S.C.; Black, G.C.; Robson, A.; Holder, G.E.; et al. The Phenotypic Variability of Retinal Dystrophies Associated With Mutations in CRX, With Report of a Novel Macular Dystrophy Phenotype. Investig. Opthalmol. Vis. Sci. 2014, 55, 6934-6944. [CrossRef]

131. Huang, L.; Xiao, X.; Li, S.; Jia, X.; Wang, P.; Guo, X.; Zhang, Q. CRX variants in cone-rod dystrophy and mutation overview. Biochem. Biophys. Res. Commun. 2012, 426, 498-503. [CrossRef]

132. Hanein, S.; Perrault, I.; Gerber, S.; Tanguy, G.; Barbet, F.; Ducroq, D.; Calvas, P.; Dollfus, H.; Hamel, C.; Löppönen, T.; et al. Leber congenital amaurosis: Comprehensive survey of the genetic heterogeneity, refinement of the clinical definition, and genotype-phenotype correlations as a strategy for molecular diagnosis. Hum. Mutat. 2004, 23, 306-317. [CrossRef]

133. Kumaran, N.; Pennesi, M.E.; Yang, P.; Trzupek, K.M.; Schlechter, C.; Moore, A.T.; Weleber, R.G.; Michaelides, M. Leber Congenital Amaurosis/Early-Onset Severe Retinal Dystrophy Overview. In GeneReviews $((R))$; Adam, M.P., Ardinger, H.H., Pagon, R.A., Wallace, S.E., Bean, L.J.H., Stephens, K., Amemiya, A., Eds.; University of Washington: Seattle, WA, USA, 1993.

134. Hollander, A.I.D.; Roepman, R.; Koenekoop, R.K.; Cremers, F.P. Leber congenital amaurosis: Genes, proteins and disease mechanisms. Prog. Retin. Eye Res. 2008, 27, 391-419. [CrossRef] [PubMed]

135. Tran, N.M.; Chen, S. Mechanisms of blindness: Animal models provide insight into distinct CRX-associated retinopathies. Dev. Dyn. 2014, 243, 1153-1166. [CrossRef]

136. Acland, G.M.; Aguirre, G.D. Retinal degenerations in the dog: IV. Early retinal degeneration (erd) in the Norwegian elkhound. Exp. Eye Res. 1987, 44, 491-521. [CrossRef]

137. Goldstein, O.; Kukekova, A.V.; Aguirre, G.D.; Acland, G.M. Exonic SINE insertion in STK38L causes canine early retinal degeneration (erd). Genomics 2010, 96, 362-368. [CrossRef] [PubMed]

138. Berta, Á.I.; Boesze-Battaglia, K.; Genini, S.; Goldstein, O.; O’Brien, P.J.; Szél, Á.; Acland, G.M.; Beltran, W.A.; Aguirre, G.D. Photoreceptor Cell Death, Proliferation and Formation of Hybrid Rod/S-Cone Photoreceptors in the Degenerating STK38L Mutant Retina. PLoS ONE 2011, 6, e24074. [CrossRef] [PubMed]

139. Zeitz, C.; Jacobson, S.G.; Hamel, C.P.; Bujakowska, K.M.; Neuillé, M.; Orhan, E.; Zanlonghi, X.; Lancelot, M.-E.; Michiels, C.; Schwartz, S.B.; et al. Whole-Exome Sequencing Identifies LRIT3 Mutations as a Cause of Autosomal-Recessive Complete Congenital Stationary Night Blindness. Am. J. Hum. Genet. 2013, 92, 67-75. [CrossRef]

140. Kondo, M.; Das, R.; Imai, R.; Santana, E.; Nakashita, T.; Imawaka, M.; Ueda, K.; Ohtsuka, H.; Sakai, K.; Aihara, T.; et al. A Naturally Occurring Canine Model of Autosomal Recessive Congenital Stationary Night Blindness. PLoS ONE 2015, 10, e0137072. [CrossRef]

141. Das, R.; Becker, D.; Jagannathan, V.; Goldstein, O.; Santana, E.; Carlin, K.; Sudharsan, R.; Leeb, T.; Nishizawa, Y.; Kondo, M.; et al. Genome-wide association study and whole-genome sequencing identify a deletion in LRIT3 associated with canine congenital stationary night blindness. Sci. Rep. 2019, 9, 14166. [CrossRef]

142. Oh, A.; Loew, E.R.; Foster, M.L.; Davidson, M.G.; English, R.V.; Gervais, K.J.; Herring, I.; Mowat, F.M. Phenotypic characterization of complete CSNB in the inbred research beagle: How common is CSNB in research and companion dogs? Doc. Ophthalmol. 2018, 137, 87-101. [CrossRef]

143. Hasan, N.; Pangeni, G.; Cobb, C.A.; Ray, T.A.; Nettesheim, E.R.; Ertel, K.J.; Lipinski, D.M.; McCall, M.A.; Gregg, R.G. Presynaptic Expression of LRIT3 Transsynaptically Organizes the Postsynaptic Glutamate Signaling Complex Containing TRPM1. Cell Rep. 2019, 27, 3107-3116. [CrossRef]

144. Morgans, C.; Zhang, J.; Jeffrey, B.G.; Nelson, S.M.; Burke, N.S.; Duvoisin, R.M.; Brown, R.L. TRPM1 is required for the depolarizing light response in retinal ON-bipolar cells. Proc. Natl. Acad. Sci. USA 2009, 106, 19174-19178. [CrossRef] [PubMed]

145. Morgans, C.; Brown, R.L.; Duvoisin, R.M. TRPM1: The endpoint of the mGluR6 signal transduction cascade in retinal ON-bipolar cells. BioEssays 2010, 32, 609-614. [CrossRef] [PubMed] 
146. Witzel, D.A.; Smith, E.L.; Wilson, R.D.; Aguirre, G.D. Congenital stationary night blindness: An animal model. Investig. Ophthalmol. Vis. Sci. 1978, 17, 788-795.

147. Sandmeyer, L.S.; Breaux, C.B.; Archer, S.; Grahn, B.H. Clinical and electroretinographic characteristics of congenital stationary night blindness in the Appaloosa and the association with the leopard complex. Veter Ophthalmol. 2007, 10, 368-375. [CrossRef] [PubMed]

148. Bellone, R.; Brooks, S.A.; Sandmeyer, L.; Murphy, B.A.; Forsyth, G.; Archer, S.; Bailey, E.; Grahn, B. Differential Gene Expression of TRPM1, the Potential Cause of Congenital Stationary Night Blindness and Coat Spotting Patterns (LP) in the Appaloosa Horse (Equus caballus). Genetics 2008, 179, 1861-1870. [CrossRef] [PubMed]

149. Audo, I.; Kohl, S.; Leroy, B.P.; Munier, F.L.; Guillonneau, X.; Mohand-Saïd, S.; Bujakowska, K.M.; Nandrot, E.F.; Lorenz, B.; Preising, M.; et al. TRPM1 Is Mutated in Patients with Autosomal-Recessive Complete Congenital Stationary Night Blindness. Am. J. Hum. Genet. 2009, 85, 720-729. [CrossRef]

150. Li, Z.; Sergouniotis, P.I.; Michaelides, M.; Mackay, D.; Wright, G.A.; Devery, S.; Moore, A.T.; Holder, G.E.; Robson, A.; Webster, A.R. Recessive Mutations of the Gene TRPM1 Abrogate ON Bipolar Cell Function and Cause Complete Congenital Stationary Night Blindness in Humans. Am. J. Hum. Genet. 2009, 85, 711-719. [CrossRef]

151. Van Genderen, M.M.; Bijveld, M.M.; Claassen, Y.B.; Florijn, R.J.; Pearring, J.N.; Meire, F.M.; McCall, M.A.; Riemslag, F.C.; Gregg, R.G.; Bergen, A.A.; et al. Mutations in TRPM1 Are a Common Cause of Complete Congenital Stationary Night Blindness. Amer. J. Human Genet. 2009, 85, 730-736. [CrossRef]

152. Bellone, R.; Holl, H.; Setaluri, V.; Devi, S.; Maddodi, N.; Archer, S.; Sandmeyer, L.; Ludwig, A.; Förster, D.; Pruvost, M.; et al. Evidence for a Retroviral Insertion in TRPM1 as the Cause of Congenital Stationary Night Blindness and Leopard Complex Spotting in the Horse. PLoS ONE 2013, 8, e78280. [CrossRef]

153. Littink, K.W.; Van Genderen, M.M.; Collin, R.W.; Roosing, S.; De Brouwer, A.P.M.; Riemslag, F.C.C.; Venselaar, H.; Thiadens, A.A.H.J.; Hoyng, C.; Rohrschneider, K.; et al. A Novel Homozygous Nonsense Mutation inCABP4Causes Congenital Cone-Rod Synaptic Disorder. Investig. Opthalmol. Vis. Sci. 2009, 50, 2344-2350. [CrossRef]

154. Marinho, L.L.P.; Occelli, L.M.; Pasmanter, N.; Somma, A.T.; Montiani-Ferreira, F.; Petersen-Jones, S.M. Autosomal recessive night blindness with progressive photoreceptor degeneration in a dog model. Investig. Ophthalmol. Vis. Sci. 2019, 60, 465.

155. Somma, A.T.; Moreno, J.C.D.; Sato, M.T.; Rodrigues, B.D.; Occelli, L.M.; Bacellar-Galdino, M.; Petersen-Jones, S.M.; Montiani-Ferreira, F. Characterization of a novel form of progressive retinal atrophy in Whippet dogs: A clinical, electroretinographic, and breeding study. Veter Ophthalmol. 2016, 20, 450-459. [CrossRef] [PubMed]

156. Kropatsch, R.; Petrasch-Parwez, E.; Seelow, D.; Schlichting, A.; Gerding, W.M.; Akkad, D.A.; Epplen, J.T.; Dekomien, G. Generalized progressive retinal atrophy in the Irish Glen of Imaal Terrier is associated with a deletion in the ADAM9 gene. Mol. Cell. Probes 2010, 24, 357-363. [CrossRef] [PubMed]

157. Goldstein, O.; Mezey, J.G.; Boyko, A.R.; Gao, C.; Wang, W.; Bustamante, C.D.; Anguish, L.J.; Jordan, J.A.; Pearce-Kelling, S.E.; Aguirre, G.D.; et al. An ADAM9 mutation in canine cone-rod dystrophy 3 establishes homology with human cone-rod dystrophy 9. Mol. Vis. 2010, 16, 1549-1569. [PubMed]

158. Sohocki, M.M.; Perrault, I.; Leroy, B.P.; Payne, A.; Dharmaraj, S.; Bhattacharya, S.S.; Kaplan, J.; Maumenee, I.H.; Koenekoop, R.; Meire, F.M.; et al. Prevalence of AIPL1 Mutations in Inherited Retinal Degenerative Disease. Mol. Genet. Metab. 2000, 70, 142-150. [CrossRef]

159. Van Der Spuy, J.; Kim, J.H.; Yu, Y.S.; Szel, A.; Luthert, P.J.; Clark, B.J.; Cheetham, M.E. The expression of the Leber congenital amaurosis protein AIPL1 coincides with rod and cone photoreceptor development. Investig. Opthalmol. Vis. Sci. 2003, 44, 5396-5403. [CrossRef]

160. Kumaran, N.; Moore, A.T.; Weleber, R.G.; Michaelides, M. Leber congenital amaurosis/early-onset severe retinal dystrophy: Clinical features, molecular genetics and therapeutic interventions. Br. J. Ophthalmol. 2017, 101, 1147-1154. [CrossRef]

161. Sohocki, M.M.; Bowne, S.J.; Sullivan, L.S.; Blackshaw, S.; Cepko, C.L.; Payne, A.M.; Bhattacharya, S.S.; Khaliq, S.; Mehdi, S.Q.; Birch, D.G.; et al. Mutations in a new photoreceptor-pineal gene on 17p cause Leber congenital amaurosis. Nat. Genet. 2000, 24, 79-83. [CrossRef]

162. Gopalakrishna, K.N.; Boyd, K.; Yadav, R.P.; Artemyev, N.O. Aryl Hydrocarbon Receptor-interacting Protein-like 1 Is an Obligate Chaperone of Phosphodiesterase 6 and Is Assisted by the $\gamma$-Subunit of Its Client. J. Boil. Chem. 2016, 291, 16282-16291. [CrossRef] 
163. Hidalgo-De-Quintana, J.; Evans, R.J.; Cheetham, M.E.; Van Der Spuy, J. The Leber congenital amaurosis protein AIPL1 functions as part of a chaperone heterocomplex. Investig. Opthalmol. Vis. Sci. 2008, 49, 2878-2887. [CrossRef]

164. Ramamurthy, V.; Niemi, G.A.; Reh, T.A.; Hurley, J.B. Leber congenital amaurosis linked to AIPL1: A mouse model reveals destabilization of cGMP phosphodiesterase. Proc. Natl. Acad. Sci. USA 2004, 101, 13897-13902. [CrossRef]

165. Yadav, R.P.; Artemyev, N.O. AIPL1: A specialized chaperone for the phototransduction effector. Cell. Signal. 2017, 40, 183-189. [CrossRef]

166. Kolandaivelu, S.; Singh, R.K.; Ramamurthy, V. AIPL1, A protein linked to blindness, is essential for the stability of enzymes mediating cGMP metabolism in cone photoreceptor cells. Hum. Mol. Genet. 2013, 23, 1002-1012. [CrossRef]

167. Rah, H.; Maggs, D.J.; Blankenship, T.N.; Narfström, K.; Lyons, L.A. Early-Onset, Autosomal Recessive, Progressive Retinal Atrophy in Persian Cats. Investig. Opthalmol. Vis. Sci. 2005, 46, 1742-1747. [CrossRef] [PubMed]

168. Lyons, L.A.; Creighton, E.K.; Alhaddad, H.; Beale, H.; Grahn, R.; Rah, H.; Maggs, D.J.; Helps, C.; Gandolfi, B. Whole genome sequencing in cats, identifies new models for blindness in AIPL1 and somite segmentation in HES7. BMC Genom. 2016, 17, 265. [CrossRef] [PubMed]

169. Ahonen, S.; Arumilli, M.; Seppälä, E.; Hakosalo, O.; Kaukonen, M.K.; Komaromy, A.M.; Lohi, H. Increased Expression of MERTK is Associated with a Unique Form of Canine Retinopathy. PLoS ONE 2014, 9, e114552. [CrossRef] [PubMed]

170. Fanning, T.; Singer, M. LINE-1: A mammalian transposable element. Biochim. Biophys. Acta (BBA) Gene Struct. Expr. 1987, 910, 203-212. [CrossRef]

171. Everson, R.; Pettitt, L.; Forman, O.P.; Dower-Tylee, O.; McLaughlin, B.; Ahonen, S.; Kaukonen, M.; Komaromy, A.M.; Lohi, H.; Mellersh, C.S.; et al. An intronic LINE-1 insertion in MERTK is strongly associated with retinopathy in Swedish Vallhund dogs. PLoS ONE 2017, 12, e0183021. [CrossRef] [PubMed]

172. Zangerl, B.; Goldstein, O.; Philp, A.R.; Lindauer, S.J.; Pearce-Kelling, S.E.; Mullins, R.F.; Graphodatsky, A.; Ripoll, D.; Felix, J.S.; Stone, E.M.; et al. Identical mutation in a novel retinal gene causes progressive rod-cone degeneration in dogs and retinitis pigmentosa in humans. Genomics 2006, 88, 551-563. [CrossRef]

173. Nevet, M.J.; Shalev, S.A.; Zlotogora, J.; Mazzawi, N.; Ben-Yosef, T. Identification of a prevalent founder mutation in an Israeli Muslim Arab village confirms the role of PRCD in the aetiology of retinitis pigmentosa in humans. J. Med. Genet. 2010, 47, 533-537. [CrossRef]

174. Allon, G.; Mann, I.; Remez, L.; Sehn, E.; Rizel, L.; Nevet, M.J.; Perlman, I.; Wolfrum, U.; Ben-Yosef, T. PRCD is Concentrated at the Base of Photoreceptor Outer Segments and is Involved in Outer Segment Disc Formation. Hum. Mol. Genet. 2019, 28, 4078-4088. [CrossRef] [PubMed]

175. Spencer, W.J.; Pearring, J.N.; Salinas, R.Y.; Loiselle, D.R.; Skiba, N.P.; Arshavsky, V.Y. Progressive Rod-Cone Degeneration (PRCD) Protein Requires N-Terminal S-Acylation and Rhodopsin Binding for Photoreceptor Outer Segment Localization and Maintaining Intracellular Stability. Biochemistry 2016, 55, 5028-5037. [CrossRef]

176. Spencer, W.J.; Ding, J.-D.; Lewis, T.R.; Yu, C.; Phan, S.; Pearring, J.N.; Kim, K.-Y.; Thor, A.; Mathew, R.; Kalnitsky, J.; et al. PRCD is essential for high-fidelity photoreceptor disc formation. Proc. Natl. Acad. Sci. USA 2019, 116, 13087-13096. [CrossRef]

177. Aguirre, G.D.; Alligood, J.; O’Brien, P.; Buyukmihci, N. Pathogenesis of progressive rod-cone degneration in miniature poodles. Investig. Ophthalmol. Vis. Sci. 1982, 23, 610-630.

178. Friedman, J.S.; Chang, B.; Kannabiran, C.; Chakarova, C.; Singh, H.; Jalali, S.; Hawes, N.L.; Branham, K.; Othman, M.; Filippova, E.; et al. Premature Truncation of a Novel Protein, RD3, Exhibiting Subnuclear Localization Is Associated with Retinal Degeneration. Am. J. Hum. Genet. 2006, 79, 1059-1070. [CrossRef] [PubMed]

179. Wolf, E.D.; Vainisi, S.J.; Santos-Anderson, R. Rod-cone dysplasia in the collie. J. Am. Veter Med Assoc. 1978, $173,1331-1333$.

180. Woodford, B.; Liu, Y.; Fletcher, R.; Chader, G.; Farber, D.; Santos-Anderson, R.; Tso, M.O. Cyclic nucleotide metabolism in inherited retinopathy in collies: A biochemical and histochemical study. Exp. Eye Res. 1982, 34, 703-714. [CrossRef] 
181. Dizhoor, A.M.; Olshevskaya, E.V.; Peshenko, I.V. Retinal guanylyl cyclase activation by calcium sensor proteins mediates photoreceptor degeneration in an rd3 mouse model of congenital human blindness. J. Boil. Chem. 2019, 294, 13729-13739. [CrossRef]

182. Kukekova, A.V.; Goldstein, O.; Johnson, J.; Richardson, M.A.; Pearce-Kelling, S.E.; Swaroop, A.; Friedman, J.S.; Aguirre, G.D.; Acland, G.M. Canine RD3 mutation establishes rod-cone dysplasia type 2 (rcd2) as ortholog of human and murine rd3. Mamm. Genome 2009, 20, 109-123. [CrossRef]

183. Santos-Anderson, R.M.; Tso, M.O.; Wolf, E.D. An inherited retinopathy in collies. A light and electron microscopic study. Investig. Ophthalmol. Vis. Sci. 1980, 19, 1282-1294.

(C) 2020 by the authors. Licensee MDPI, Basel, Switzerland. This article is an open access article distributed under the terms and conditions of the Creative Commons Attribution (CC BY) license (http://creativecommons.org/licenses/by/4.0/). 